\title{
Corporate Response to Distress: Evidence from the Asian Financial Crisis
}

\author{
Rajdeep Sengupta and Mara Faccio
}

\begin{abstract}
This paper provides a comprehensive examination of corporate responses to financial distress during an economy-wide crisis, specifically through the restructuring of assets (through asset sales, mergers, or liquidations) and/or liabilities. Using firm-level data from five countries hardest hit by the East Asian financial crisis of 1997-98, this study contrasts the effects that financial and corporate governance variables have on restructuring choices. The study finds that, during a crisis, financial constraints and corporate governance each have a large effect on restructuring choices. (JEL G33, G34)
\end{abstract}

Federal Reserve Bank of St. Louis Review, March/April 2011, 93(2), pp. 127-54.

\section{BACKGROUND}

$\mathbf{F}$ inancial crises are widely believed to have long-lasting effects. Typically, recovery involves deleveraging from significant increases in debt incurred during the buildup to the crisis. On the one hand, widespread defaults on household debt may be at center stage of such crises, as in the ongoing financial crisis in the United States. On the other hand, as Reinhart and Rogoff (2009, p. 251) point out, "it may be worthwhile to consider widespread corporate default as yet another variety of crisis." Such crises manifest as large-scale corporate defaults, as happened during the East Asian financial crisis of 1997-98. This paper studies corporate responses to economy-wide and firm-level distress, specifically efforts to restructure (deleverage) in the aftermath of a financial crisis.

Understanding the determinants of firms' responses in the wake of a financial crisis is important for reducing the costs of a financial crisis. Deleveraging can be a costly, laborious process by which firms repay or draw down debt. It not only has adverse effects on employment and economic growth, but also can significantly forestall innovation and entrepreneurship. Typically, deleveraging involves creditor workouts and/or asset sales. In the former, a firm renegotiates repayment of its obligations; in the latter, a firm uses the proceeds from divestiture to repay debt. Firms often use multiple means to successfully reduce financial distress.

We use company-level data from the East Asian crisis of 1997-98 to study the deleveraging process and the determinants of corporate responses to distress. This example is relevant for several reasons. First, it allows us to study a large sample of distressed firms in different countries affected by the crisis. Second, as elaborated below, it allows us to study both the financial and nonfinancial determinants of corporate responses. Third, with the benefit of hindsight, it allows us to study firms that have experienced significant financial distress (both economy-wide and firmlevel) followed by a strong recovery. Such success is in contrast to the experience of some countries recurrently affected by crises, especially those in Latin America, which have relapsed into economic distress.

Rajdeep Sengupta is an economist at the Federal Reserve Bank of St. Louis. Mara Faccio is the associate professor of finance and the Hanna chair in entrepreneurship at Krannert School of Management at Purdue University.

(C) 2011, The Federal Reserve Bank of St. Louis. The views expressed in this article are those of the author(s) and do not necessarily reflect the views of the Federal Reserve System, the Board of Governors, or the regional Federal Reserve Banks. Articles may be reprinted, reproduced, published, distributed, displayed, and transmitted in their entirety if copyright notice, author name(s), and full citation are included. Abstracts, synopses, and other derivative works may be made only with prior written permission of the Federal Reserve Bank of St. Louis. 
A firm in financial distress typically cannot meet its debt repayment obligations using its liquid assets. Unless its performance recovers, the distressed firm is likely to default on its debt, which could lead to a formal bankruptcy filing, a dismissal of management personnel, and possibly liquidation of the firm (e.g., see Gilson, 1989). To avoid such actions, firms typically respond by restructuring their assets (by fire sales, mergers, acquisitions, or capital-expenditure reductions), liabilities (by restructuring bank loans or public debt and through injections of new capital from outside sources), or both. Although corporate responses to economy-wide and firm-level distress are essentially the same, it is possible that the determinants of these responses differ under the two conditions.

Although firms have several restructuring options, most of the literature on firms in distress has focused on a given type of response to distress (and the costs thereof), primarily for U.S. firms. ${ }^{1}$ We could find only two exceptions. The first is a paper by Asquith, Gertner, and Scharfstein (1994) in which the authors provide a comprehensive analysis of several different forms of financial restructuring. They find that the structure of a firm's liabilities is the most important determinant of its response to financial distress, while performance-related variables have no explanatory power. Their paper focuses on corporate responses under firm-level rather than economywide financial distress. The second exception is a recent paper by Atanassov and Kim (2006). They take a broader approach-across several countries-and look at the determinants of asset sales, layoffs, and managerial turnover in response to firm-specific distress. Their study focuses primarily on regulatory variables; they argue that the restructuring option chosen depends largely on the degree of investor protection and labor laws in a given country.

Despite the macroeconomic implications of an economy-wide financial crisis, we know of

\footnotetext{
1 This literature includes work by Brown, James, and Mooradian (1993) on public debt and bank debt restructurings; Gilson (1990) on bank debt restructurings; Brown, James, and Mooradian (1994) on asset sales; Erwin and McConnell (1997) on piecemeal voluntary liquidations; Tashjian, Lease, and McConnell (1996) on prepackaged bankruptcies; and Ang, Chua, and McConnell (1982), Franks and Torous (1989), and Hotchkiss (1994) on bankruptcy filings.
}

no comprehensive study that explores the specific ways firms-including U.S. firms-try to avoid liquidation during an economic downturn. This is an important distinction between our paper and other related work on corporate restructuring under financial distress. ${ }^{2}$ In particular, we focus on the aftermath of the East Asian crisis of 199798 in the economies of Indonesia, Malaysia, the Philippines, South Korea, and Thailand. These five countries are widely believed to be those most affected by that crisis (Radelet and Sachs, 1998). This particular focus allows us not only to study corporate responses when all companies face an economy-wide crisis but also to compile and compare the determinants of corporate responses for companies that face firm-level distress during a period of economy-wide distress.

An important distinction of this study is that we contrast two sets of determinants of corporate responses to financial distress: (i) governance variables and (ii) capital structure and performance variables. We specifically investigate the role of business groups and family ownership, which represent the prevalent form of corporate control outside Anglo-Saxon systems. In East Asia, most large firms are closely held conglomerates-structured as business groups-as opposed to the widely held corporations that prevail in the United States and United Kingdom (La Porta, Lopez-de-Silanes, and Shleifer, 1999; and Claessens, Djankov, and Lang, 2000). Given that during our study period the control of corporate assets was concentrated in the hands of a few wealthy families (organized as groups), it would be instructive to know whether group affiliation and ownership type played any role in the resolution of the financial distress of these firms. For example, earlier work by Lang, Poulsen, and Stulz (1995) shows that, absent financial distress, entrenched U.S. managers engage in suboptimal divestiture decisions when such practice allows them to pursue their personal goals. More recently, Faccio, Masulis, and McConnell (2006) show that

\footnotetext{
2 In work related to but different from ours, Claessens, Djankov, and Klapper (2003) analyze the likelihood of formal (versus informal) bankruptcy filings during the East Asian crisis. They find that bankruptcy filings are less common for bank-owned and groupaffiliated firms.
} 
politically connected (typically family) firms are especially likely to receive a bailout from their home government during a crisis.

An important consideration in the resolution of distress involves the negotiations between the distressed firm and its creditors. Banks are often part of business groups and known to give firms affiliated with the group, particularly firms in distress, preferential access to capital. This is partly because group affiliation lessens capital-market frictions. ${ }^{3}$ This makes bank-led creditor workouts easier for group-affiliated firms. ${ }^{4}$ Moreover, conglomerates often provide sufficient cross guarantees to bail out troubled members within their group. ${ }^{5}$ Group affiliation therefore dilutes the information available to an outside creditor. In a crisis situation, this opacity may help groupaffiliated firms by creating a greater likelihood of creditor bailouts. Kim (2004) specifically argues that conglomeration is a device designed by firms to maximize the chance of bailout in the event of a default on their bank loans. His model demonstrates that a bank has more difficulty inferring the quality of members within a business group than that of stand-alone firms because intergroup loan guarantees prevent a bank from knowing whether a payment is from the borrower or from other firms in the group. Consequently, the bank is more likely to liquidate a freestanding firm than an otherwise identical group-affiliated firm. Our study provides an opportunity to determine whether this theoretical hypothesis holds true in practice.

3 The literature on relationship banking documents that asymmetric information problems make it difficult for a firm to initiate a lending relationship with a bank while hold-up problems make it difficult for firms to switch banks. Such problems are mitigated if both the bank and firm are part of the same conglomerate.

4 Morck, Wolfenzon, and Yeung (2005) argue that pyramid firms can also enjoy cheaper access to capital than freestanding firms even when banks are not part of the pyramid group. This could occur either because apex firms of the group can serve as banks or because the superior bargaining power of such conglomerations reduces rent-seeking by outside banks.

5 Friedman, Johnson, and Mitton (2002) record instances of controlling shareholders propping up distressed firms in their group (to the benefit of public shareholders) to attract external financing. While Hoshi, Kashyap, and Scharfstein (1991) view such interfirm transfers as enhancing economic efficiency by reducing bankruptcy costs, Morck and Nakamura (1999) present evidence that such transactions also include bailouts of inefficient firms.
Regarding capital structure, it is known that debt has been the primary source of external financing in East Asia and that some corporations were highly leveraged. In a world of unavoidable bankruptcy costs, the characteristics of a firm's capital structure influence the likelihood of bankruptcy and the magnitude of the costs incurred (Senbet and Seward, 1995). An additional feature of Asian economies is that firms had incentives to delay debt, operational restructuring, and even repayment of loans because of weak foreclosure and bankruptcy laws in their given countries. Bankruptcy reforms were necessary not only to ensure actual firm failures but also to enable creditors and debtors to reach out-of-court settlements (see Claessens, Djankov, and Mody, 2001, for details).

We examine financial responses to economywide distress for 622 firms from the five Asian countries most severely affected by the East Asian financial crisis of 1997-98. The responses were recorded over a six-year period from 1998 to 2003. Of the total responses, restructuring liabilities through creditor workouts emerges as firms' mostfavored response (21.86 percent), followed by asset sales (14.63 percent), which include the selling of divisions and the reduction of property, plant, and equipment holdings. Mergers and acquisitions are third (3.9 percent). Only 10 firms in our sample were liquidated over the sample period.

We use duration analysis to examine the determinants of three responses to distress: (i) asset sales, (ii) creditor workouts, and (iii) mergers and acquisitions. In particular, we adopt a stratified Cox relative risk hazard model using time-varying covariates to determine the hazard of each response. There are several advantages to adopting this framework for our regression analysis. First, unlike more commonly used discreteoutcome models, hazard models use data more efficiently by explicitly incorporating information about the timing of alternative responses. Second, this framework allows a firm to have multiple responses, even within the same year, as seen in the data. Third, this method allows covariates, especially financial variables, to vary with time. Fourth, our estimation procedure allows us to 
check for robustness using data conditional on firm-level distress. In addition, stratifying our sample by country allows us to control for countrywide differences in institutions (i.e., the rules, practices, and organizations that govern the economy).

Our results are as follows. We find that financial and governance variables influence the response hazard but their influence varies with each response. The creditor workout hazard decreases with increases in the proportion of intangible assets or the interest coverage ratio. The asset sale hazard increases with firm size, while the merger hazard increases with a firm's earning potential (return on equity [ROE]). In addition, the asset sale hazard decreases but the merger hazard increases with higher concentrations of ownership. However, both effects are largely attributable to large blockholders not involved with management. Finally, political connections and group affiliation each increase the hazard ratios for all three responses. Notably, group affiliation has the largest effect on the merger hazard. Moreover, group affiliation increases the hazard of creditor workouts, which supports the theory of conglomeration advanced in Kim (2004).

\section{DATA SOURCES AND DEFINITIONS OF VARIABLES}

\section{Financial Data and Corporate Distress}

This paper uses firm-level data for the five countries most severely affected by the East Asian financial crisis of 1997-98: Indonesia, Malaysia, the Philippines, South Korea, and Thailand. Firms in these countries were selected on the basis of three criteria. First, the financial data for each firm had to be reported in the Worldscope database, which is the primary source for accounting data. Unless otherwise noted, we use company financial reports from the Worldscope database between 1993 and 2002. Second, each firm had to be included in the ownership dataset compiled by Claessens, Djankov, and Lang (2000) (further detailed below). Third, the primary business segment of each firm could not be in financial services-that is, not in the Standard Industrial Classification (SIC) 6000-6999. Excluding all unleveraged companies, the final sample consists of 622 firms. In general, the sample is representative of larger firms that trade on the major stock exchanges in each country.

Using firm-level financial data, we classify a firm as "financially distressed" 6 if the company had any year with (i) earnings before interest and taxes (EBIT) less than its reported interest expense or (ii) operating income less than its reported interest expense. ${ }^{7}$ Accordingly, we define a dummy variable at the firm level, distress, that takes the value 1 if for any year either of these two conditions is satisfied. Using this definition, 458 of 622 firms are classified as distressed.

At first glance, it appears that such a strong selection condition could impose a bias in our sample selection and classify most of the firms in our sample as distressed. However, it is important to understand that, while our criterion for classification captures a firm's inability to make its interest payments for a given year, it does not include criteria that would measure its potential to pay down its stock of debt. This becomes relevant when comparing distressed versus nondistressed firms because distressed firms appear to be highly leveraged. Table 1 shows that both measures of leverage-the debt-to-asset ratio and the debt-to-equity ratio-are significantly higher for distressed firms. The debt-to-asset ratio is the ratio of a firm's total liabilities to its total assets, and the debt-to-equity ratio is the ratio of a firm's total liabilities to its common equity. That distressed firms are more highly leveraged can be viewed as reaffirmation of the distinction between distressed and nondistressed firms.

Following the abundant literature on responses to financial distress, we list the finan-

\footnotetext{
6 Any measure of distress would need to use a financial metric and is likely to be arbitrary. However, this distinction at the firm level is largely to select a subset of firms to make a distinction between economy-wide distress and firm-level distress. As our robustness check results reveal later, the distinction does not appear to be important in our sample.

7 Operating income is the difference between operating revenues and operating expenses, as opposed to nonoperating income, which is attributed to the portion of an organization's income that is derived from activities not related to its core operations. EBIT is the sum of an organization's operating and nonoperating income.
} 


\section{Table 1}

\section{Firm Summary Statistics}

\begin{tabular}{|c|c|c|c|c|}
\hline Variables & & All firms & Distressed firms & Nondistressed firms \\
\hline Number of firms & & 622 & 458 & 164 \\
\hline \multirow[t]{2}{*}{ Firm size (USD thousands) } & Mean & $1,105.39$ & $1,163.78$ & 373.53 \\
\hline & Median & 239.50 & 247.11 & 168.33 \\
\hline \multirow[t]{2}{*}{ Debt-to-asset ratio } & Mean & 0.68 & 0.71 & 0.33 \\
\hline & Median & 0.62 & 0.64 & 0.32 \\
\hline \multirow[t]{2}{*}{ Debt-to-equity ratio } & Mean & 6.45 & 6.91 & 0.71 \\
\hline & Median & 1.30 & 1.44 & 0.47 \\
\hline Group affiliation & Percent & 59.00 & 62.01 & 50.61 \\
\hline Political connection & Percent & 13.34 & 11.14 & 19.51 \\
\hline Management ownership & Percent & 66.72 & 63.74 & 75.00 \\
\hline Pyramid ownership & Percent & 32.79 & 35.16 & 26.22 \\
\hline \multirow[t]{2}{*}{ Firms in group } & Mean & 9.70 & 9.15 & 11.76 \\
\hline & Median & 8 & 8 & 9 \\
\hline \multirow[t]{2}{*}{ Banks in group } & Mean & 2.65 & 2.59 & 2.88 \\
\hline & Median & 2 & 2 & 2 \\
\hline \multirow[t]{2}{*}{ Largest blockholder ownership } & Mean & 27.40 & 26.21 & 31.15 \\
\hline & Median & 23.53 & 21.57 & 27.93 \\
\hline
\end{tabular}

NOTE: A firm is classified as financially distressed if for any year between 1998 and 2002 the company had earnings before EBIT or operating income less than its reported interest expense. Firm size is the log of a firm's total assets measured in thousands of U.S. dollars (USD). The debt-to-asset ratio is a firm's total liabilities divided by its total assets. The debt-to-equity ratio is a firm's total liabilities divided by its total common equity. These three financial variables are calculated for all financial years between 1998 and 2002. The dummy variable group affiliation indicates whether a company is part of a major business group (Claessens, Djankov, and Lang, 2000). Political connection indicates that at least one of a firm's top directors (CEO, president, vice president, or secretary) or large shareholders (any blockholder controlling at least 10 percent of shareholder votes) is a member of parliament, a government minister, or closely related to a top politician or party official (Faccio, Masulis, and McConnell, 2006). The dummy variable management ownership takes the value 1 if a firm's CEO or board chairman or vice chairman is part of the controlling ownership and 0 otherwise (Claessens, Djankov, and Lang, 2000). The dummy variable pyramid ownership takes the value 1 if the firm is controlled through a pyramid structure (Claessens, Djankov, and Lang, 2000). Firms in group is the total number of firms in a group (to which a firm is affiliated) when group affiliation $=1$. Banks in group is the total number of banks and financial companies in a group (to which a firm is affiliated) when group affiliation $=1$. Largest blockholder ownership is the holdings percentage of the largest shareholder.

cial variables (ratios) deemed important determinants of responses to distress. A significant indicator of distress is the interest coverage ratio (Asquith, Gertner, and Scharfstein, 1994). It is computed as EBIT divided by the total interest payable. The interest coverage ratio is a measure of a company's ability to honor its debt payments. ${ }^{8}$ In addition, Brown, James, and Mooradian (1994) show that performance is the most important predictor of bankruptcy and reorganization. As a proxy for the company's accounting performance,

8 Notably, we have used the interest coverage ratio both as a determinant of responses and as a selection criterion for firm-level distress, which undoubtedly raises some obvious concerns about selection bias. However, it is important to mention that our estimation procedure extends to all firms and not just those in distress. The selection bias assumes importance when we repeat our estimation for companies that experience firm-level distress as a check for robustness of our results. 
we use a standard financial ratio, ROE. We also control for market expectations of recovery through the variable market value/book ratio (MB ratio), which is the market value of equity (ordinary and preferred) plus the book value of total debt divided by the book value of total assets (Gilson, Kose, and Lang, 1990; and Asquith, Gertner, and Scharfstein, 1994). The book value of total assets is the sum of total current assets, long-term receivables, investments in unconsolidated subsidiaries, other investments, net property, plants, equipment, and other assets. Finally, we also include the variable firm size, which is the log of the company's market capital or total assets measured in thousands of U.S. dollars (USD). We include this variable because (i) the choice for a workout is likely to depend on a company's size and its borrowing capability and (ii) it is widely believed that larger firms have better access to credit markets even when they are constrained (Beck, Demirgüç-Kunt, and Maksimovic, 2008).

Lastly, we include an additional variable, the intangible assets ratio. Gilson, John, and Lang (1990, p. 323) argue that "creditor consent is harder to obtain when there is greater asymmetry in the information used by the stockholders and creditors to value the firm." They also point out that the information asymmetry regarding the value of the firm increases with the proportion of intangible assets because such assets, by their nature, are difficult to value. Therefore, a greater proportion of intangible assets relative to total assets is likely to reduce the willingness of creditors to enter into debt restructuring with the firm. For this reason, we hypothesize that the intangible asset ratio is an important determinant of creditor workouts.

\section{Event Data}

As mentioned earlier, both economy-wide distress and firm-level distress can lead firms to make similar responses. We consider only the financial responses listed below and denote these as "events" and "responses" interchangeably. Event data collected for each firm are from the publicly available Asia Pacific News Archives of the Troubled Company Reporter (TCR) on the website of the InterNet Bankruptcy Library (IBL). ${ }^{9}$ The TCR reports information related to the financial distress of publicly traded companies worldwide, including regulatory filings, court pleadings, judicial rulings, and press reports. The event data cover the period February 1, 1998 (the date the TCR starts covering distress), to December 31, 2003. The financial responses are classified as (i) creditor workouts, also known as debt restructuring, (ii) asset sales, which include property sales and sales of divisions, (iii) mergers, and (iv) liquidations. In each case, the date (year) of the event is also noted.

We define creditor workouts as agreements between a firm and its creditors to modify any terms of outstanding financial claims (either public or private) currently held against the firm. Common workout methods include one or more of the following: an exchange offer (debt for equity), covenant modification, maturity extension, or interest rate adjustment. The creditor workouts category also includes injections of capital by creditors. ${ }^{10}$ In fact, the TCR news archives reveal that workouts were often packaged to include a combination of rescheduling, debtequity swaps, and capital injections by creditors. Also, creditor workouts are the most prevalent event in our sample: 136 companies (21.86 percent) used creditor workouts to successfully restructure their liabilities during the sample period.

Firms also use asset sales to resolve financial distress. Brown, James, and Mooradian (1994) point out that distressed firms primarily use asset sales because of pressure from creditors, often to the detriment of stockholders. ${ }^{11}$ In particular, they argue that the probability that asset sales are used to repay debt increases with a firm's leverage and decreases with its operating performance. They also find that firms using asset sales have this distinguishing characteristic: They operate

\footnotetext{
9 The TCR lists data by date; see www.bankrupt.com/TCRAP Public/index.html.

${ }^{10}$ Some authors, such as Senbet and Seward (1995), have treated capital injections by creditors as a separate category.

${ }^{11}$ However, Lang, Poulsen, and Stulz (1995) find that asset sales used to retire debt result in an abnormally high (positive) average stock return compared with sales proceeds retained by the firm.
} 
multiple divisions and subsidiaries. As a result, diversified groups are more likely than freestanding firms to use asset sales. Moreover, managers that respond favorably to creditor pressure to undertake asset sales are more likely to retain control of the firm. We find that 91 distressed firms in our sample (14.63 percent) sold part or all of their assets.

In addition, 24 firms (3.9 percent) either merged with another company or were acquired. Only 10 firms were liquidated. This may be largely because our sample includes mostly larger firms with better access to capital markets. However, there is an additional reason for the fewer liquidations: Forbearance by creditors is often more likely during an economic crisis (Peek and Rosengreen, 2003). Naturally, a firm exits our sample if it undergoes a merger, liquidation, or both. The appendix includes articles from the $T C R$ archive for each noted financial response.

\section{Governance Variables}

In addition to financial and response variables, this study includes another set of determinants of financial responses-governance factors. We specifically investigate the role of business groups, political connections, and ownership concentration (the prevalent form of corporate control outside Anglo-Saxon systems). For business group affiliation, we use data from Claessens, Djankov, and Lang (2000), who compile several data sources to identify whether a company is part of a major business group. Following their paper, group affiliation is a dummy variable that takes the value 1 for all companies that are a part of a business group and 0 otherwise. We use the group affiliation variable to study the effect of group affiliation on each response to corporate distress. As mentioned before, Kim (2004) predicts a higher likelihood of a debt workout for group-affiliated than stand-alone firms.

Earlier work by Faccio, Masulis, and McConnell (2006) shows that many Asian firms were owned by key politicians (or people close to them) and frequently received government aid during the crisis. Therefore, we control for a given company having political ties. Following their paper, political connection is a dummy variable that takes the value 1 if at least one of a firm's top directors (CEO, president, vice president, or secretary) or large shareholders (any blockholder controlling at least 10 percent of votes) is a member of parliament, a government minister, or closely related to a top politician or party and 0 otherwise. If these companies receive indirect aid from the government, we would expect not only a higher incidence of workouts, but also more-frequent asset sales (particularly if politicians can exert pressure on prospective buyers). ${ }^{12}$

Finally, we include two variables to study measures of ownership concentration largely following Claessens, Djankov, and Lang (2000) and Mitton (2002), respectively. The first variable is largest blockholder ownership, defined as the ownership percentage (in terms of cash flow rights) of the largest shareholder in the firm. The second variable is summed ownership concentration, defined as the total holding of all shareholders that own 5 percent or more stock, which identifies when ownership is not concentrated with an individual but with a group. To differentiate between ownership blocks held by those involved in management and those held by others, Mitton (2002) uses largest management blockholder concentration and largest nonmanagement blockholder concentration. We also use these governance measures to explain the differences in the modes of each response.

\section{SUMMARY STATISTICS}

Tables 1 to 4 report summary statistics. We use annual financial data from 1998 through 2003 to calculate financial variables for each firm over all years for which data are available. In contrast, we calculate governance and ownership variables using pre-crisis data and treat these variables as time invariant due to data limitations. ${ }^{13}$ These

\footnotetext{
${ }^{12}$ We refine some of these variables further to distinguish between the types of controlling shareholders (for example, families or governments) and determine whether a firm is part of a group that includes a bank. However, these variables do not explain the likelihood of any of the responses.

${ }^{13}$ For the observation dates for the governance and ownership data, see the sources in Claessens, Djankov, and Lang (2000); Mitton (2002); and Faccio, Masulis, and McConnell (2006).
} 
Table 2

Distribution of Responses by Country

\begin{tabular}{|c|c|c|c|c|c|c|}
\hline & Indonesia & Malaysia & Philippines & South Korea & Thailand & Total \\
\hline \multicolumn{7}{|l|}{ Panel A: Full sample } \\
\hline Number of firms & 102 & 151 & 69 & 212 & 88 & 622 \\
\hline \multicolumn{7}{|l|}{ Response } \\
\hline Creditor workouts & 30 & 27 & 13 & 33 & 33 & 136 \\
\hline Asset sales & 7 & 42 & 6 & 21 & 15 & 91 \\
\hline Merger & 3 & 3 & 5 & 9 & 4 & 24 \\
\hline Liquidation & 0 & 1 & 2 & 7 & 0 & 10 \\
\hline Total responses & 40 & 73 & 26 & 70 & 52 & 261 \\
\hline \multicolumn{7}{|l|}{ Ownership structure } \\
\hline Group affiliation (mean) & 0.71 & 0.58 & 0.74 & 0.53 & 0.50 & 0.59 \\
\hline Largest blockholder ownership (\%) & 47.21 & 30.89 & 36.76 & 15.99 & 39.88 & 27.40 \\
\hline \multicolumn{7}{|l|}{ Panel B: Distressed firms } \\
\hline Number of firms & 92 & 66 & 56 & 180 & 64 & 458 \\
\hline \multicolumn{7}{|l|}{ Response } \\
\hline Creditor workouts & 30 & 13 & 11 & 32 & 31 & 117 \\
\hline Asset sales & 7 & 19 & 6 & 19 & 12 & 63 \\
\hline Merger & 2 & 2 & 2 & 8 & 3 & 17 \\
\hline Liquidation & 0 & 1 & 1 & 7 & 0 & 9 \\
\hline Total responses & 39 & 35 & 20 & 66 & 46 & 206 \\
\hline \multicolumn{7}{|l|}{ Ownership structure } \\
\hline Group affiliation (mean) & 0.74 & 0.59 & 0.73 & 0.58 & 0.48 & 0.62 \\
\hline Largest blockholder ownership (\%) & 46.65 & 31.30 & 36.76 & 15.97 & 35.46 & 26.21 \\
\hline
\end{tabular}

NOTE: Creditor workouts include agreements between a firm and its creditors to modify any terms of outstanding financial claims currently held against the firm (for both public and private loan agreements). Asset sales include the sales of assets and divestitures in subsidiaries or divisions to retire debt. Mergers includes firms that merged or were taken over during 1998-2003. Liquidations include firms liquidated during 1998-2003. A given company may have multiple responses at the same time. See note for Table 1 for additional definitions.

SOURCE: Data on responses of distressed firms are from the publicly available archives of the IBL website.

statistics are calculated across all firms as opposed to all firm-years.

Table 1 shows how firms in distress differ from their nondistressed peers. Our sample includes 622 firms: 458 classified as distressed (according to our definition) and 164 that failed to enter distress at any point during our sample period. As evident from Table 1, distressed firms tend to be much larger in size-measured in terms of total assets in USD. Not surprisingly, they also tend to be more highly leveraged. On average, a greater proportion of distressed firms are affiliated with business groups or have pyramid ownership. Conversely, a smaller proportion of distressed firms have a political connection or management ownership. Distressed firms with a group affiliation have, on average, fewer firms and banks in those groups. In addition, the average holdings of a firm's largest shareholder are higher for nondistressed than for distressed firms.

Table 2 provides country-level summary statistics for the full sample of firms (Panel A) and 


\section{Table 3}

\section{Distribution of Responses by Year}

\begin{tabular}{|c|c|c|c|c|c|}
\hline & Creditor workouts & Asset sales & Mergers & Liquidations & Total \\
\hline \multicolumn{6}{|c|}{ Panel A: Full sample } \\
\hline 1998 & 19 & 15 & 3 & 0 & 37 \\
\hline 1999 & 26 & 13 & 6 & 4 & 49 \\
\hline 2000 & 42 & 12 & 5 & 2 & 61 \\
\hline 2001 & 22 & 24 & 5 & 3 & 54 \\
\hline 2002 & 19 & 19 & 4 & 0 & 43 \\
\hline 2003 & 8 & 8 & 1 & 1 & 17 \\
\hline Total & 136 & 91 & 24 & 10 & 261 \\
\hline \multicolumn{6}{|c|}{ Panel B: Distressed firms } \\
\hline 1998 & 17 & 10 & 3 & 0 & 30 \\
\hline 1999 & 26 & 8 & 5 & 4 & 43 \\
\hline 2000 & 38 & 7 & 1 & 1 & 47 \\
\hline 2001 & 20 & 20 & 4 & 3 & 47 \\
\hline 2002 & 12 & 12 & 3 & 0 & 27 \\
\hline 2003 & 4 & 6 & 1 & 1 & 12 \\
\hline Total & 117 & 63 & 17 & 9 & 206 \\
\hline
\end{tabular}

NOTE: See notes for Tables 1 and 2 for definitions.

SOURCE: Data on responses of distressed firms are from the publicly available archives of the IBL website.

distressed firms only (Panel B). The number of firms in each country ranges from 69 in the Philippines to 212 in South Korea. In the full sample, there are a total of 261 responses. The number of firms recording responses was fewer than 261, however, because a single firm could have multiple responses. Interestingly, the distribution of each response (as a proportion of total firms) appears to be evenly spread across the countries. The sole exception is Malaysia, which has a disproportionately large number of firms using asset sales. However, when one conditions on distressed firms, this difference is no longer as large. For the full sample, the average largest blockholder ownership is 27.40 percent. The lowest average is in South Korea, with a mean of 15.99 percent, and the highest is in Indonesia, with a mean of 47.21 percent. For the full sample, 59 percent of firms are part of a business group, with a high of 74 percent in the Philippines and a low of 48 percent in Thailand. Interestingly, for distressed firms, group affiliation and largest blockholder ownership are only marginally different on average than for all firms in the sample.

Table 3 shows the distribution of responses to distress by year for all firms (Panel A) and distressed firms only (Panel B). The onset of the crisis in East Asia was largely during 1997-98. The majority of responses occurred two to three years after the crisis. Not surprisingly, responses peak around the years 2000 and 2001 and decline thereafter. However, we recorded responses through 2003 to include those (such as creditor workouts) that undergo multiple, possibly lengthy rounds of negotiations to reach an agreement (see Appendix A for such an example).

Table 4 shows for the full sample (Panel A) and distressed firms only (Panel B) the distribution of the four responses based on firm characteristics. The columns labeled " 1 " and " 0 " indicate firms with and without responses, respectively. 
Table 4

Summary Statistics by Response Type

\begin{tabular}{|c|c|c|c|c|c|c|c|c|c|}
\hline & & \multicolumn{2}{|c|}{ Creditor workouts } & \multicolumn{2}{|c|}{ Mergers } & \multicolumn{2}{|c|}{ Asset sales } & \multicolumn{2}{|c|}{ Liquidations } \\
\hline & & 1 & 0 & 1 & 0 & 1 & 0 & 1 & 0 \\
\hline \multicolumn{10}{|l|}{ Panel A: Full sample } \\
\hline Number of firms & & 136 & 486 & 24 & 598 & 91 & 531 & 10 & 612 \\
\hline \multirow[t]{2}{*}{ Firm size (USD thousands) } & Mean & $1,613.64$ & 944.70 & $1,751.37$ & $1,080.15$ & $1,735.83$ & $1,010.51$ & $2,949.69$ & $1,072.54$ \\
\hline & Median & 393.74 & 212.37 & 845.90 & 229.73 & 729.54 & 213.11 & 326.45 & 238.95 \\
\hline Group affiliation & Percent & 61.80 & 58.23 & 75 & 58.36 & 68.10 & 57.44 & 50 & 59.15 \\
\hline Political connection & Percent & 18.40 & 11.93 & 12.50 & 13.38 & 22 & 11.86 & 0 & 13.56 \\
\hline Management ownership & Percent & 62.20 & 67.98 & 79.20 & 66.22 & 68.90 & 66.35 & 50 & 67 \\
\hline Pyramid ownership & Percent & 37.80 & 31.41 & 41.70 & 32.44 & 36.70 & 32.14 & 30 & 32.84 \\
\hline \multirow[t]{2}{*}{ Firms in group } & Mean & 8.41 & 10.09 & 8.69 & 9.76 & 10.75 & 9.50 & 9.20 & 9.71 \\
\hline & Median & 7 & 9 & 8 & 8 & 9 & 8 & 9 & 8 \\
\hline \multirow[t]{2}{*}{ Banks in group } & Mean & 2.42 & 2.72 & 3.44 & 2.61 & 2.81 & 2.62 & 2.20 & 2.66 \\
\hline & Median & 2 & 2 & 3 & 2 & 2 & 2 & 1 & 2 \\
\hline \multirow{2}{*}{$\begin{array}{l}\text { Largest blockholder } \\
\text { ownership }\end{array}$} & Mean & 26.91 & 27.59 & 29.58 & 27.29 & 23.26 & 28.45 & 11.68 & 27.67 \\
\hline & Median & 23.55 & 23.53 & 26.68 & 22.71 & 21.28 & 23.88 & 9.72 & 23.81 \\
\hline \multicolumn{10}{|l|}{ Panel B: Distressed firms } \\
\hline Number of firms & & 117 & 341 & 17 & 441 & 63 & 395 & 9 & 449 \\
\hline \multirow[t]{2}{*}{ Firm size (USD thousands) } & Mean & $1,535.82$ & 980.26 & $2,051.38$ & $1,101.91$ & $1,931.58$ & $1,006.39$ & $3,230.57$ & $1,089.89$ \\
\hline & Median & 399.12 & 255.43 & $1,151.20$ & 275.59 & 804.30 & 255.51 & 355.13 & 287.25 \\
\hline Group affiliation & Percent & 62.39 & 61.88 & 76.47 & 61.45 & 69.84 & 60.76 & 55.56 & 62.14 \\
\hline Political connection & Percent & 18.80 & 8.50 & 5.88 & 11.34 & 17.46 & 10.13 & 0 & 11.36 \\
\hline Management ownership & Percent & 60.34 & 64.90 & 76.47 & 63.24 & 59.68 & 64.38 & 55.56 & 63.90 \\
\hline Pyramid ownership & Percent & 38.79 & 33.92 & 47.06 & 34.70 & 38.71 & 34.61 & 33.33 & 35.20 \\
\hline \multirow[t]{2}{*}{ Firms in group } & Mean & 8.24 & 9.47 & 10 & 9.11 & 9.97 & 9 & 9.20 & 9.15 \\
\hline & Median & 7 & 9 & 8 & 8 & 9 & 8 & 9 & 8 \\
\hline \multirow[t]{2}{*}{ Banks in group } & Mean & 2.32 & 2.69 & 3.91 & 2.53 & 2.95 & 2.53 & 2.20 & 2.60 \\
\hline & Median & 1.50 & 2 & 3 & 2 & 2 & 2 & 1 & 2 \\
\hline \multirow{2}{*}{$\begin{array}{l}\text { Largest blockholder } \\
\text { ownership }\end{array}$} & Mean & 27.82 & 25.45 & 29.34 & 26.02 & 22.93 & 26.86 & 11.68 & 26.54 \\
\hline & Median & 22.10 & 21.26 & 26.24 & 21.21 & 20.58 & 22.01 & 9.72 & 22.01 \\
\hline
\end{tabular}

NOTE: The column headings " 1 " and " 0 " indicate firms with and without a response, respectively. See notes for Tables 1 and 2 for definitions.

SOURCE: Data on responses of distressed firms are from the publicly available archives of the IBL website. 
In Panel A, firm size (measured as total assets in USD) is greater for firms with a response than for those without. The group of firms that responds with mergers has the highest percentage of firms with a group affiliation, management ownership, and pyramid ownership. Firms in this group also tend to have more banks in their business groups on average and the largest average largest blockholder ownership. In contrast, the group of firms that liquidate has the lowest percentage of firms with a group affiliation, political connection, management ownership, and pyramid ownership. Firms in this group also have the lowest percentage of banks in their business groups and the lowest average largest blockholder ownership.

Panel B has few qualitative differences from Panel A. Firm size is still larger for firms with a response than those without. The differences between the two panels for group affiliation, political connection, management ownership, and pyramid ownership are around 5 percentage points. One exception is the percentage of firms with management ownership that use asset sales, which decreases 9.22 percentage points, from 68.9 percent for the full sample to 59.68 percent for distressed firms only.

\section{METHODOLOGY}

Our aim is to examine the hazard of corporate responses to financial distress. To understand the determinants of a particular event (response), we estimate a semiparametric hazard regression for the event. The hazard function $\lambda(t)$ is the (instantaneous) probability of the occurrence of the event at year $t$ and is given by

$$
\lambda(t)=\lim _{\Delta t \rightarrow 0} \frac{\operatorname{Pr}(t \leq T<t+\Delta t \mid T \geq t)}{\Delta t} .
$$

We assume that the causal processes are different for each event. Our starting point is the relative risk model developed in Cox (1972),

$$
\lambda(t \mid \boldsymbol{x})=\lambda_{0}(t) \exp \boldsymbol{x}^{\prime} \beta,
$$

where $\boldsymbol{x}$ is a vector of measured covariates and $\beta$ is a vector of parameters. ${ }^{14}$ The hazard $\lambda(t \mid \mathbf{x})$ gives the rate of response per unit time period at time $t$.
This model assumes a baseline hazard, $\lambda_{0}(t)$, which is identical for all firms in the sample. The covariates in $\boldsymbol{x}$ influence the overall hazard for each firm through the exponential term in equation (1). The baseline hazard is of unspecified form and, hence, is nonparametric. Along with the parametric exponential form in equation (1), we estimate a semiparametric model. The hazard specification in equation (1) makes it sufficiently flexible to adapt to our problem of corporate responses to financial distress.

First, the model allows a firm to make multiple responses even within the same year. Moreover, the occurrence of one such event does not preclude others, except in the case of a merger or liquidation, whereupon the firm exits our sample. ${ }^{15}$ We consider three responses to financial distress: creditor workouts, asset sales, and mergers. ${ }^{16}$ Liquidations and mergers denote a firm's exit from our sample but, given their obvious differences, we classify them separately. However, we do not analyze liquidations because few occur in our sample; thus, their information content is low and unbiased estimates are unlikely (Hsieh, Manski, and McFadden, 1985).

Second, the baseline hazard can be allowed to vary in specific subsets of data. Typically, such stratification is useful when some explanatory

\footnotetext{
14 The object of interest in a Cox proportional hazard regression model is the hazard ratio, which can be interpreted as a multiplicative change in the instantaneous probability of delinquency for a marginal change in a particular risk characteristic. It seems that the hazard ratio is analogous to the odds ratio in logistic regressions. Let $\lambda(t \mid \mathbf{x})$ be the instantaneous probability of delinquency at year $t$ conditional on other characteristics given by vector $\boldsymbol{x}$. We can define the estimated hazard ratio $(H R)$ for marginal change in risk characteristic $X_{i}$ as$$
\begin{aligned}
& \widehat{H R}\left(t \mid x_{i}=x_{i}+\Delta x_{i}\right)= \\
& \frac{\lambda_{0}(t) \exp \left(x_{1} \hat{\beta}_{1}+x_{2} \hat{\beta}_{2}+\cdots+\left(x_{i}+\Delta x_{i}\right) \hat{\beta}_{i}+\cdots\right)}{\lambda_{0}(t) \exp \left(x_{1} \hat{\beta}_{1}+x_{2} \hat{\beta}_{2}+\cdots+x_{i} \hat{\beta}_{i}+\cdots\right)}=\exp \left(\Delta x_{i} \hat{\beta}_{i}\right) .
\end{aligned}
$$

This gives us $h\left(t \mid \mathbf{x}, x_{i}=x_{i}+\Delta x_{i}\right)=\lambda(t \mid \mathbf{x}) * \widehat{H R}\left(t \mid x_{i}=x_{i}+\Delta x_{i}\right)$.

${ }^{15}$ The case of alternative modes of failure, where the occurrence of a single event removes a bank from risk of the alternative event, is modeled in Wheelock and Wilson (2000). Our case differs from that of the competing-risk framework used in their study because in our study individual firms can have multiple responses to distress.

${ }^{16}$ Given the few liquidations, our estimation does not yield any explanatory power for liquidations per se.
} 


\section{Sengupta and Faccio}

variables do not appear to have a multiplicative effect on the hazard function. We take advantage of this feature and stratify by country. In doing so, the population of firms is divided into $r$ strata and the hazard $\lambda_{k}(t \mid \mathbf{x})$ in the $k$ th stratum depends on an arbitrary hazard function, $\lambda_{0 k}(t)$, and can be written for $k=1,2, \ldots, r$ as

$$
\lambda_{k}(t \mid \mathbf{x})=\lambda_{0 k}(t) \exp \boldsymbol{x}^{\prime} \beta .
$$

A stratified Cox hazard model allows us to control for countrywide differences in institutions (i.e., the rules, practices, and organizations that govern the economy). Notably, this estimation technique allows each country to have its own baseline hazard, $\lambda_{0 k}(t), k=1, \ldots r$, where $r$ is the number of countries in our sample. In this respect, our estimation technique allows us to control for the evolution of such institutional features over time.

Third, the model allows covariates to depend on time. With such time-varying covariates, $\boldsymbol{x}(t)$, the relative risk model is of the form

$$
\lambda_{k}(t \mid \mathbf{x}(t))=\lambda_{0 k}(t) \exp \boldsymbol{x}(t)^{\prime} \beta
$$

for $k=1,2, \ldots, r$, where $\boldsymbol{x}(t)$ is the set of covariates. In our case, financial covariates are time varying but governance variables are time invariant. We estimate equation (3) and provide the results below.

Finally, our estimation procedure allows us to check for robustness using data for distressed firms only. Stated differently, we can condition on financial variables to determine whether a firm is in distress and only then include it in our regression sample. Therefore, a firm enters the sample when, at any year within our sample period, the financial condition of the firm indicates distress. Thereafter, the firm remains in our sample unless it disappears because of a merger or liquidation. In this way, we try to ensure that the responses included are only those from distressed firms. It is important to note that these four generalizations do not substantially complicate the estimation of the coefficients (see Wheelock and Wilson, 2000, for details).

To formalize our estimation procedure, we describe the methodology as follows. Each firm in the sample is observed at $J_{i}$ different times, $t_{i 1}<t_{i 2}<\ldots<t_{i j}$, with either failure (exit due to merger or liquidation) or censoring occurring at time $t_{i J_{i}}$. Here, time refers not to calendar time but to time relative to the date (year) a firm first becomes distressed (the entry of the firm into the sample), so that $t_{i 0}=0$, where $t_{i 0}$ is the first date of distress for the ith firm. Financial data used in $\boldsymbol{x}(t)$ corresponding to time $t_{i j}, j=0, \ldots,\left(J_{i}-1\right)$, are assumed to reflect the financial position of the firm $i$ over the interval $\left[t_{i j}<t_{i(j+1)}\right)$. Although the financial data are assumed constant over the given interval, they may vary across the different intervals, making this estimated model time varying. In addition, the set of covariates include governance and ownership variables assumed to be unchanged throughout the sample period.

\section{ESTIMATION RESULTS}

As mentioned, the literature on corporate distress includes the study of several financial variables that are important determinants of responses to distress. In this section, we include all relevant financial variables as regressors in our baseline regression specification. To account for systematic variations of financial ratios across industries, we normalize the financial variables for each financial year using their two-digit SIC industry mean (Asquith, Gertner, and Scharfstein, 1994). Therefore, all movements of financial variables in our estimation should be interpreted as standard deviations (SDs) from their industry means. In addition to financial variables, we use different controls for governance, affiliation, and ownership concentration variables.

The regression results in Tables 5 through 7 report the hazard ratios for the six different specifications considered in this study. Each specification includes the financial variables firm size, $\mathrm{MB}$ ratio, $\mathrm{ROE}$, and interest coverage ratio. Table 5 also includes the intangible asset ratio, which is an important proxy for asymmetric information in our regressions for creditor workouts. In addition, each specification also includes additional governance variables: Columns 1 and 2 also include the political connection and group affiliation variables, respectively. Columns 3 through 


\section{Table 5}

\section{Determinants of Creditor Workouts}

Stratified Cox hazard ratios: Creditor workouts

\begin{tabular}{|c|c|c|c|c|c|c|}
\hline & \\
\hline & (1) & (2) & (3) & (4) & (5) & (6) \\
\hline Firm size & $\begin{array}{r}0.991 \\
(-0.14)\end{array}$ & $\begin{array}{r}0.987 \\
(-0.21)\end{array}$ & $\begin{array}{r}0.927 \\
(-0.98)\end{array}$ & $\begin{array}{r}0.936 \\
(-0.83)\end{array}$ & $\begin{array}{r}0.917 \\
(-1.14)\end{array}$ & $\begin{array}{r}0.927 \\
(-0.94)\end{array}$ \\
\hline Intangible asset ratio & $\begin{array}{c}0.720 \\
(-2.98)^{* * *}\end{array}$ & $\begin{array}{l}0.731 \\
(-2.84)^{* * *}\end{array}$ & $\begin{array}{c}0.586 \\
(-3.25)^{* * *}\end{array}$ & $\begin{array}{l}0.583 \\
(-3.10)^{* * *}\end{array}$ & $\begin{array}{l}0.596 \\
(-3.26)^{* * *}\end{array}$ & $\begin{array}{l}0.586 \\
(-3.19)^{* * *}\end{array}$ \\
\hline MB ratio & $\begin{array}{r}0.733 \\
(-1.46)\end{array}$ & $\begin{array}{r}0.748 \\
(-1.35)\end{array}$ & $\begin{array}{r}0.850 \\
(-0.68)\end{array}$ & $\begin{array}{r}0.852 \\
(-0.64)\end{array}$ & $\begin{array}{r}0.858 \\
(-0.65)\end{array}$ & $\begin{array}{r}0.862 \\
(-0.64)\end{array}$ \\
\hline ROE & $\begin{array}{l}1.097 \\
(0.74)\end{array}$ & $\begin{array}{l}1.090 \\
(0.65)\end{array}$ & $\begin{array}{l}1.153 \\
(1.10)\end{array}$ & $\begin{array}{l}1.137 \\
(1.06)\end{array}$ & $\begin{array}{l}1.141 \\
(1.05)\end{array}$ & $\begin{array}{l}1.147 \\
(1.08)\end{array}$ \\
\hline Interest coverage ratio & $\begin{array}{l}0.583 \\
(-3.85)^{* * *}\end{array}$ & $\begin{array}{l}0.583 \\
(-3.83)^{* * *}\end{array}$ & $\begin{array}{c}0.605 \\
(-2.12)^{* *}\end{array}$ & $\begin{array}{c}0.609 \\
(-2.00)^{* *}\end{array}$ & $\begin{array}{c}0.592 \\
(-2.29)^{* *}\end{array}$ & $\begin{array}{c}0.591 \\
(-2.21)^{* *}\end{array}$ \\
\hline Political connection & $\begin{array}{c}1.688 \\
(1.49)\end{array}$ & & & & & \\
\hline Group affiliation & & $\begin{array}{l}1.580 \\
(3.06)^{* * *}\end{array}$ & & & & \\
\hline $\begin{array}{l}\text { Largest blockholder } \\
\text { ownership }\end{array}$ & & & $\begin{array}{r}0.985 \\
(-1.33)\end{array}$ & & & \\
\hline $\begin{array}{l}\text { Summed ownership } \\
\text { concentration }\end{array}$ & & & & $\begin{array}{r}0.990 \\
(-0.85)\end{array}$ & & \\
\hline $\begin{array}{l}\text { Largest management } \\
\text { blockholder concentration }\end{array}$ & & & & & $\begin{array}{r}0.980 \\
(-0.92)\end{array}$ & \\
\hline $\begin{array}{l}\text { Largest nonmanagement } \\
\text { blockholder concentration }\end{array}$ & & & & & & $\begin{array}{r}0.994 \\
(-0.52)\end{array}$ \\
\hline Log pseudo-likelihood & -299.11 & -298.59 & -152.47 & -152.80 & -152.85 & -153.00 \\
\hline Number of firms & 452 & 452 & 181 & 181 & 181 & 181 \\
\hline Number of responses (events & 71 & 71 & 42 & 42 & 42 & 42 \\
\hline Number of observations & 2,672 & 2,672 & 1,171 & 1,171 & 1,171 & 1,171 \\
\hline \multicolumn{7}{|c|}{$\begin{array}{l}\text { NOTE: The intangible asset ratio is the book value of intangible assets divided by the book value of total assets. The MB ratio is the } \\
\text { market value of equity (ordinary and preferred) plus book value of total debt divided by the book value of total assets. ROE is share- } \\
\text { holder net income divided by the year-end book value of shareholder equity (\%). The interest coverage ratio is EBIT divided by the } \\
\text { total interest expense. Summed ownership concentration is the sum of all shareholders owning } 5 \text { percent or more of the company. } \\
\text { Largest management blockholder concentration indicates the largest blockholder is an officer of the firm (Mitton, 2002). Largest non- } \\
\text { management blockholder concentration indicates the largest blockholder is not an officer of the firm. See notes for Tables } 1 \text { and } 2 \text { for } \\
\text { additional definitions. Numbers in parentheses are } z \text {-statistics; }{ }^{*},{ }^{* *} \text {, and }{ }^{* * *} \text { indicate statistical significance at the 10, 5, and } 1 \text { percent } \\
\text { levels, respectively. }\end{array}$} \\
\hline
\end{tabular}




\section{Sengupta and Faccio}

6 also include the ownership concentration variables: largest blockholder ownership, summed ownership concentration, largest management blockholder, and largest nonmanagement blockholder concentration, respectively.

Column 1 of Table 5 reports regression results for the noted financial variables and the political connection dummy variable. For the interest coverage ratio, the point estimate of the regression coefficient is -0.539 and the hazard ratioreported in Table 5-is obtained by exponentiating the coefficient as $e^{-0.539}=0.583$. The negative coefficient implies that an increase in the interest coverage ratio from its annual industry (two-digit SIC) mean significantly reduces the hazard of creditor workouts. Stated differently, the 0.583 hazard ratio implies that a 1-SD increase in the interest coverage ratio from its annual SIC twodigit industry mean reduces the creditor workout hazard by 41.7 percent. A similar interpretation can be made for the dummy variable group affiliation. As shown in column 2 of Table 5, the point estimate of the hazard ratio for group affiliation is 1.580 . This means that the creditor workout hazard for a firm with a business group affiliation is 1.580 times (58 percent) greater than that for a firm without a group affiliation.

\section{Creditor Workouts}

As shown in Table 5, two of the five financial variables have significant explanatory power for the hazard of creditor workouts. A 1-SD increase in the intangible asset ratio from its industry mean decreases the hazard of creditor workouts by 0.583 to 0.731 times the hazard of its (industry) mean value. Arguably, creditors were less likely to restructure terms of debt for firms with a greater proportion of intangible assets because there is greater asymmetry in the information stockholders and creditors use to value the firm (Gilson, John, and Lang, 1990). Not surprisingly, a 1-SD increase in the interest coverage ratio from its industry mean reduces the hazard of creditor workouts by 0.583 to 0.609 times the hazard of its (industry) mean value. Clearly, the greater the ability of a firm to honor its debt payments, the less likely it will restructure its debt. Notably, however, neither firm size (total assets), ROE (earning potential), nor the $\mathrm{MB}$ ratio (growth prospects) are significant determinants of creditor workouts.

Governance variables do have significant explanatory power for a firm's decision to restructure its liabilities during financial distress. Group affiliation significantly increases the likelihood of creditor workouts. Firms in a business group are substantially more likely to undertake creditor workouts than their unaffiliated peers. Interestingly, this result provides strong support for the arguments in Kim (2004). As shown in column 1 of Table 5, firms with a political connection are 1.688 times more likely than firms without a political connection to engage in creditor workouts. Although these results are in line with earlier studies, such as Faccio, Masulis, and McConnell (2006), they are not statistically significant in our sample. We also use two measures of ownership concentration. Since these measures are expressed in percentage terms, the variables are scaled by 100. Largest blockholder ownership and summed ownership concentration each decrease the likelihood of creditor workouts, but the results are not statistically significant in our sample.

\section{Asset Sales}

Not surprisingly, our results in Table 6 also show that firm size is an important determinant of asset sales. A 1-SD increase in firm size from its annual industry (two-digit SIC) mean increases the hazard of asset sales by 1.466 times the hazard of its (industry) mean value. Interestingly, however, other financial variables, such as the proxies for earning potential (ROE), growth prospects (the $\mathrm{MB}$ ratio), and debt repayment capacity (the interest coverage ratio), seem to adversely affect the hazard of asset sales.

Although the effects of these financial variables are not statistically significant, the governance variables have significant explanatory power. The hazard of asset sales for firms with a group affiliation or political connection is roughly 1.8 times that of firms without such an affiliation or connection. However, the point estimate for the group affiliation dummy variable is significant at the 10 percent level, whereas that for the political connection is significant at the 5 percent 


\section{Table 6}

\section{Determinants of Asset Sales}

\section{Stratified Cox hazard ratios: Asset sales}

\begin{tabular}{|c|c|c|c|c|c|c|}
\hline & \\
\hline & (1) & (2) & (3) & (4) & (5) & (6) \\
\hline Firm size & $\begin{array}{l}1.466 \\
(6.18)^{* * *}\end{array}$ & $\begin{array}{l}1.473 \\
(5.36)^{* * *}\end{array}$ & $\begin{array}{l}1.428 \\
(2.96)^{* * *}\end{array}$ & $\begin{array}{l}1.432 \\
(2.92)^{* * *}\end{array}$ & $\begin{array}{l}1.392 \\
(2.46)^{* *}\end{array}$ & $\begin{array}{l}1.464 \\
(3.09)^{* * *}\end{array}$ \\
\hline $\mathrm{MB}$ ratio & $\begin{array}{r}0.961 \\
(-0.27)\end{array}$ & $\begin{array}{r}0.988 \\
(-0.08)\end{array}$ & $\begin{array}{r}0.753 \\
(-1.23)\end{array}$ & $\begin{array}{r}0.751 \\
(-1.25)\end{array}$ & $\begin{array}{r}0.773 \\
(-1.16)\end{array}$ & $\begin{array}{r}0.754 \\
(-1.24)\end{array}$ \\
\hline ROE & $\begin{array}{r}1.061 \\
(0.29)\end{array}$ & $\begin{array}{r}1.030 \\
(0.14)\end{array}$ & $\begin{array}{c}0.777 \\
(-1.65)^{*}\end{array}$ & $\begin{array}{r}0.799 \\
(-1.56)\end{array}$ & $\begin{array}{r}0.817 \\
(-1.38)\end{array}$ & $\begin{array}{r}0.783 \\
(-1.60)\end{array}$ \\
\hline Interest coverage ratio & $\begin{array}{c}0.764 \\
(-2.66)^{* * *}\end{array}$ & $\begin{array}{c}0.761 \\
(-2.68)^{* * *}\end{array}$ & $\begin{array}{r}0.947 \\
(-0.23)\end{array}$ & $\begin{array}{r}0.889 \\
(-0.48)\end{array}$ & $\begin{array}{r}0.831 \\
(-0.82)\end{array}$ & $\begin{array}{r}0.908 \\
(-0.41)\end{array}$ \\
\hline Political connection & $\begin{array}{l}1.817 \\
(2.02)^{* *}\end{array}$ & & & & & \\
\hline Group affiliation & & $\begin{array}{c}1.815 \\
(1.80)^{*}\end{array}$ & & & & \\
\hline $\begin{array}{l}\text { Largest blockholder } \\
\text { ownership }\end{array}$ & & & $\begin{array}{c}0.955 \\
(-2.65)^{* * *}\end{array}$ & & & \\
\hline $\begin{array}{l}\text { Summed ownership } \\
\text { concentration }\end{array}$ & & & & $\begin{array}{r}0.982 \\
(-0.72)\end{array}$ & & \\
\hline $\begin{array}{l}\text { Largest management } \\
\text { blockholder concentration }\end{array}$ & & & & & $\begin{array}{c}1.014 \\
(0.45)\end{array}$ & \\
\hline $\begin{array}{l}\text { Largest nonmanagement } \\
\text { blockholder concentration }\end{array}$ & & & & & & $\begin{array}{c}0.962 \\
(-2.43)^{* *}\end{array}$ \\
\hline Log pseudo-likelihood & -160.59 & -160.22 & -68.90 & -71.25 & -71.78 & -69.68 \\
\hline Number of firms & 453 & 453 & 181 & 181 & 181 & 181 \\
\hline Number of responses (events) & 41 & 41 & 20 & 20 & 20 & 20 \\
\hline Number of observations & 2,693 & 2,693 & 1,176 & 1,176 & 1,176 & 1,176 \\
\hline
\end{tabular}

NOTE: Numbers in parentheses are $z$-statistics; ${ }^{*}, * *$, and ${ }^{* * *}$ indicate statistical significance at the 10, 5, and 1 percent levels, respectively. See notes for Tables 1, 2, and 5 for definitions.

level. Importantly, ownership concentration reduces the hazard of asset sales. A 1 percent increase in largest blockholder ownership reduces the hazard of asset sales by 0.955 times the hazard of its (industry) mean value. Perhaps of greater significance are the differences in the effects of the largest management blockholder and largest nonmanagement blockholder variables. While the former increases the hazard of asset sales, the latter reduces it. Stated differently, we find that the decreased hazard of asset sales from high concentrations of ownership is largely attributable to large blockholders not involved with management.

\section{Mergers}

As shown in Table 7, unlike for credit workouts and asset sales, ROE has strong explanatory power for mergers, indicated by the statistically (and economically) significant point estimate of the merger hazard ratio for ROE. A 1-SD increase in ROE from its mean value increases the hazard of a merger by twice the hazard of its (industry) mean value. Since mergers tend to occur among firms with higher operating performance, this finding seems to indicate that the mergers in our sample were not necessarily in response to distress. 
Table 7

\section{Determinants of Mergers}

\begin{tabular}{|c|c|c|c|c|c|c|}
\hline & \multicolumn{6}{|c|}{ Stratified Cox hazard ratios: Mergers } \\
\hline & (1) & (2) & (3) & (4) & (5) & (6) \\
\hline Firm size & $\begin{array}{l}1.223 \\
(2.17)^{* *}\end{array}$ & $\begin{array}{c}1.167 \\
(1.65)^{*}\end{array}$ & $\begin{array}{r}0.896 \\
(-0.83)\end{array}$ & $\begin{array}{r}0.835 \\
(-0.85)\end{array}$ & $\begin{array}{r}0.963 \\
(-0.45)\end{array}$ & $\begin{array}{r}0.813 \\
(-1.60)\end{array}$ \\
\hline $\mathrm{MB}$ ratio & $\begin{array}{r}0.607 \\
(-1.56)\end{array}$ & $\begin{array}{c}0.563 \\
(-2.19)^{* *}\end{array}$ & $\begin{array}{r}0.759 \\
(-0.83)\end{array}$ & $\begin{array}{r}0.828 \\
(-0.53)\end{array}$ & $\begin{array}{r}0.424 \\
(-1.36)\end{array}$ & $\begin{array}{r}0.686 \\
(-1.26)\end{array}$ \\
\hline ROE & $\begin{array}{l}1.974 \\
(7.88)^{* * *}\end{array}$ & $\begin{array}{l}1.998 \\
(9.52)^{* * *}\end{array}$ & $\begin{array}{l}2.112 \\
(4.94)^{* * *}\end{array}$ & $\begin{array}{l}2.312 \\
(5.04)^{* * *}\end{array}$ & $\begin{array}{l}1.963 \\
(5.20)^{* * *}\end{array}$ & $\begin{array}{l}2.108 \\
(5.17)^{* * *}\end{array}$ \\
\hline Interest coverage ratio & $\begin{array}{c}0.523 \\
(-2.06)^{* *}\end{array}$ & $\begin{array}{c}0.543 \\
(-1.88)^{*}\end{array}$ & $\begin{array}{r}0.388 \\
(-1.08)\end{array}$ & $\begin{array}{r}0.306 \\
(-1.32)\end{array}$ & $\begin{array}{r}0.449 \\
(-0.96)\end{array}$ & $\begin{array}{r}0.408 \\
(-1.00)\end{array}$ \\
\hline Political connection & $\begin{array}{c}1.548 \\
(0.56)\end{array}$ & & & & & \\
\hline Group affiliation & & $\begin{array}{c}3.978 \\
(1.66)^{*}\end{array}$ & & & & \\
\hline $\begin{array}{l}\text { Largest blockholder } \\
\text { ownership }\end{array}$ & & & $\begin{array}{l}1.055 \\
(2.96)^{* * *}\end{array}$ & & & \\
\hline $\begin{array}{l}\text { Summed ownership } \\
\text { concentration }\end{array}$ & & & & $\begin{array}{l}1.067 \\
(2.15)^{* *}\end{array}$ & & \\
\hline $\begin{array}{l}\text { Largest management } \\
\text { blockholder concentration }\end{array}$ & & & & & $\begin{array}{r}0.934 \\
(-0.87)\end{array}$ & \\
\hline $\begin{array}{l}\text { Largest nonmanagement } \\
\text { blockholder concentration }\end{array}$ & & & & & & $\begin{array}{l}1.068 \\
(3.63)^{* * *}\end{array}$ \\
\hline Log pseudo-likelihood & -49.11 & -47.40 & -25.97 & -24.88 & -26.95 & -24.92 \\
\hline Number of firms & 453 & 453 & 181 & 181 & 181 & 181 \\
\hline Number of responses (events) & 13 & 13 & 8 & 8 & 8 & 8 \\
\hline Number of observations & 2,693 & 2,693 & 1,176 & 1,176 & 1,176 & 1,176 \\
\hline
\end{tabular}

NOTE: Numbers in parentheses are $z$-statistics; ${ }^{*},{ }^{* *}$, and ${ }^{* * *}$ indicate statistical significance at the 10,5 , and 1 percent levels, respectively. See notes for Tables 1, 2, and 5 for definitions.

In addition, some of the governance variables have strong explanatory power for mergers as well. For example, the point estimate of group affiliation is significant at the 10 percent level; thus, group affiliation significantly increases the merger hazard. Both ownership concentration variables also increase the merger hazard by roughly the same amount. A 1 percent increase in either the largest blockholder ownership or the summed ownership concentration increases the merger hazard roughly by 1.06 times. Importantly, as they do for asset sales, largest management blockholder and largest nonmanagement blockholder have opposite effects. The former decreases the merger hazard and the latter increases it. Here, too, we find that the increase in the merger hazard from high concentrations of ownership is largely attributable to large blockholders not involved with management.

In summary, we find that financial and governance variables influence the response hazards but these effects depend largely on the type of response. The credit workout hazard decreases with increases in the intangible assets ratio or interest coverage ratio. The asset sale hazard increases with firm size, while the merger hazard increases with ROE. In addition, the asset sale hazard decreases but the merger hazard increases 
with higher concentrations of ownership. However, both effects are largely attributable to large blockholders not involved with management. Finally, political connections and group affiliation increase all three response hazards. Notably, group affiliation has the largest effect on the merger hazard and group affiliation increases the creditor workout hazard even more.

\section{ROBUSTNESS CHECK}

\section{Corporate Distress}

Our analysis above characterizes corporate responses to economy-wide distress. In this section, we show that the results are robust to the inclusion of distress at the firm-level only. However, there is an important caveat to this analysis. Since our classification of distressed firms uses firm-level financial data, the use of such criteria imposes a selection bias on the regression analysis. It turns out that our earlier results are robust to this selection bias.

Based on our definition, we classify 458 firms as distressed during the sample period (Panel B of Table 2). Panel B of Tables 2 and 3 show the distribution of distressed firms and their responses by country and year, respectively. Not surprisingly, comparison with the distribution for the full sample (Panel A of Tables 2 and 3) shows that most of the responses in the full sample came from distressed firms.

Tables 8 to 10 show the determinants of the three hazards, respectively, for distressed firms only. In almost all cases, the results are similar to those for the full sample, which indicates little loss of generality by conditioning on distressed firms only.

Our definition of firm-level distress is not without limitations. First, it is dichotomous and does not characterize the degree of financial distress. Therefore, when multiple events are observed for a single firm, we do not differentiate between distress levels for each event. Second, we do not allow firms to switch between the distressed and nondistressed classifications: Per our definition, once a firm is classified as distressed in any given year, it is classified as distressed for all remaining years in our sample period. To the extent that our sample of distressed firms includes firms no longer in distress, our estimates could be biased.

\section{Country-Level Variation}

To control for variations in a country's institutions, legal codes, and social patterns of dealing with economic distress, we use a stratified Cox hazard model. This model allows the baseline hazard model to be different for each stratum. An alternative form of estimation is also used by using dummy variables for each country. The results are qualitatively similar and available upon request.

\section{CONCLUSION}

This study examines corporate responses to economy-wide and firm-level distress. We adopt a duration analysis framework to study determinants of such responses. We find that financial and governance variables influence the hazard of each response but that these effects depend largely on the type of response. Needless to say, the scope of this study can be broadened further to include countries where corporations did not experience economy-wide distress at the same time as firm-level distress. This would then provide us with a counterfactual to determine how responses to firm-level distress differ between normal times and times of economy-wide distress. Broadening the scope of this exercise to different countries could also allow us to examine how countrywide differences in legal structures and bankruptcy codes affect firm-level responses. 
Table 8

Determinants of Creditor Workouts for Distressed Firms

\begin{tabular}{|c|c|c|c|c|c|c|}
\hline & \multicolumn{6}{|c|}{ Stratified Cox hazard ratios: Creditor workouts } \\
\hline & (1) & (2) & (3) & $(4)$ & (5) & $(6)$ \\
\hline Firm size & $\begin{array}{r}0.988 \\
(-0.20)\end{array}$ & $\begin{array}{r}0.988 \\
(-0.21)\end{array}$ & $\begin{array}{r}0.944 \\
(-0.74)\end{array}$ & $\begin{array}{r}0.962 \\
(-0.46)\end{array}$ & $\begin{array}{r}0.940 \\
(-0.77)\end{array}$ & $\begin{array}{r}0.950 \\
(-0.63)\end{array}$ \\
\hline Intangible asset ratio & $\begin{array}{c}0.750 \\
(-2.55)^{* *}\end{array}$ & $\begin{array}{c}0.767 \\
(-2.40)^{* *}\end{array}$ & $\begin{array}{c}0.619 \\
(-2.61)^{* * *}\end{array}$ & $\begin{array}{c}0.618 \\
(-2.48)^{* *}\end{array}$ & $\begin{array}{c}0.643 \\
(-2.66)^{* * *}\end{array}$ & $\begin{array}{c}0.624 \\
(-2.54)^{* *}\end{array}$ \\
\hline MB ratio & $\begin{array}{r}0.723 \\
(-1.29)\end{array}$ & $\begin{array}{r}0.736 \\
(-1.20)\end{array}$ & $\begin{array}{r}0.864 \\
(-0.43)\end{array}$ & $\begin{array}{r}0.822 \\
(-0.53)\end{array}$ & $\begin{array}{r}0.839 \\
(-0.50)\end{array}$ & $\begin{array}{r}0.864 \\
(-0.43)\end{array}$ \\
\hline ROE & $\begin{array}{r}1.140 \\
(1.08)\end{array}$ & $\begin{array}{c}1.128 \\
(0.95)\end{array}$ & $\begin{array}{r}1.194 \\
(1.33)\end{array}$ & $\begin{array}{r}1.162 \\
(1.22)\end{array}$ & $\begin{array}{r}1.171 \\
(1.22)\end{array}$ & $\begin{array}{r}1.185 \\
(1.29)\end{array}$ \\
\hline Interest coverage ratio & $\begin{array}{c}0.621 \\
(-2.31)^{* *}\end{array}$ & $\begin{array}{c}0.624 \\
(-2.24)^{* *}\end{array}$ & $\begin{array}{c}0.641 \\
(-1.70)^{*}\end{array}$ & $\begin{array}{r}0.660 \\
(-1.49)\end{array}$ & $\begin{array}{c}0.623 \\
(-1.76)^{*}\end{array}$ & $\begin{array}{c}0.627 \\
(-1.74)^{*}\end{array}$ \\
\hline Political connection & $\begin{array}{c}1.746 \\
(1.55)\end{array}$ & & & & & \\
\hline Group affiliation & & $\begin{array}{l}1.387 \\
(2.11)^{* *}\end{array}$ & & & & \\
\hline $\begin{array}{l}\text { Largest blockholder } \\
\text { ownership }\end{array}$ & & & $\begin{array}{r}0.978 \\
(-1.63)\end{array}$ & & & \\
\hline $\begin{array}{l}\text { Summed ownership } \\
\text { concentration }\end{array}$ & & & & $\begin{array}{r}0.984 \\
(-1.33)\end{array}$ & & \\
\hline $\begin{array}{l}\text { Largest management } \\
\text { blockholder concentration }\end{array}$ & & & & & $\begin{array}{r}0.983 \\
(-0.76)\end{array}$ & \\
\hline $\begin{array}{l}\text { Largest nonmanagement } \\
\text { blockholder concentration }\end{array}$ & & & & & & $\begin{array}{r}0.989 \\
(-0.83)\end{array}$ \\
\hline Log pseudo-likelihood & -274.87 & -275.18 & -142.16 & -142.55 & -143.07 & -142.95 \\
\hline Number of firms & 404 & 404 & 166 & 166 & 166 & 166 \\
\hline Number of responses (events) & 66 & 66 & 39 & 39 & 39 & 39 \\
\hline Number of observations & 1,931 & 1,931 & 880 & 880 & 880 & 880 \\
\hline
\end{tabular}

NOTE: Numbers in parentheses are $z$-statistics; ${ }^{*},{ }^{* *}$, and ${ }^{* * *}$ indicate statistical significance at the 10,5 , and 1 percent levels, respectively. See notes for Tables 1, 2, and 5 for definitions. 
Table 9

Determinants of Asset Sales for Distressed Firms

\begin{tabular}{|c|c|c|c|c|c|c|}
\hline & \multicolumn{6}{|c|}{ Stratified Cox hazard ratios: Asset sales } \\
\hline & (1) & (2) & (3) & (4) & (5) & $(6)$ \\
\hline Firm size & $\begin{array}{l}1.453 \\
(5.69)^{* * *}\end{array}$ & $\begin{array}{l}1.451 \\
(5.10)^{* * *}\end{array}$ & $\begin{array}{l}1.532 \\
(3.18)^{* * *}\end{array}$ & $\begin{array}{l}1.579 \\
(3.57)^{* * *}\end{array}$ & $\begin{array}{l}1.456 \\
(2.79)^{* * *}\end{array}$ & $\begin{array}{l}1.603 \\
(3.47)^{* * *}\end{array}$ \\
\hline $\mathrm{MB}$ ratio & $\begin{array}{r}0.978 \\
(-0.13)\end{array}$ & $\begin{array}{r}0.992 \\
(-0.05)\end{array}$ & $\begin{array}{c}0.620 \\
(-1.68)^{*}\end{array}$ & $\begin{array}{c}0.603 \\
(-1.65)^{*}\end{array}$ & $\begin{array}{r}0.643 \\
(-1.49)\end{array}$ & $\begin{array}{c}0.612 \\
(-1.82)^{*}\end{array}$ \\
\hline ROE & $\begin{array}{r}1.055 \\
(0.24)\end{array}$ & $\begin{array}{r}1.021 \\
(0.09)\end{array}$ & $\begin{array}{r}0.754 \\
(-1.57)\end{array}$ & $\begin{array}{r}0.782 \\
(-1.55)\end{array}$ & $\begin{array}{r}0.809 \\
(-1.27)\end{array}$ & $\begin{array}{r}0.765 \\
(-1.51)\end{array}$ \\
\hline Interest coverage ratio & $\begin{array}{r}0.819 \\
(-1.48)\end{array}$ & $\begin{array}{r}0.824 \\
(-1.40)\end{array}$ & $\begin{array}{r}0.826 \\
(-0.60)\end{array}$ & $\begin{array}{r}0.777 \\
(-0.87)\end{array}$ & $\begin{array}{r}0.692 \\
(-1.26)\end{array}$ & $\begin{array}{r}0.766 \\
(-0.86)\end{array}$ \\
\hline Political connection & $\begin{array}{r}1.521 \\
(1.11)\end{array}$ & & & & & \\
\hline Group affiliation & & $\begin{array}{r}1.635 \\
(1.47)\end{array}$ & & & & \\
\hline $\begin{array}{l}\text { Largest blockholder } \\
\text { ownership }\end{array}$ & & & $\begin{array}{l}0.935 \\
(-2.96)^{* * *}\end{array}$ & & & \\
\hline $\begin{array}{l}\text { Summed ownership } \\
\text { concentration }\end{array}$ & & & & $\begin{array}{r}0.965 \\
(-1.00)\end{array}$ & & \\
\hline $\begin{array}{l}\text { Largest management } \\
\text { blockholder concentration }\end{array}$ & & & & & $\begin{array}{l}1.019 \\
(0.61)\end{array}$ & \\
\hline $\begin{array}{l}\text { Largest nonmanagement } \\
\text { blockholder concentration }\end{array}$ & & & & & & $\begin{array}{c}0.944 \\
(-2.74)^{* * *}\end{array}$ \\
\hline Log pseudo-likelihood & -139.71 & -139.21 & -56.34 & -59.17 & -60.63 & -57.33 \\
\hline Number of firms & 404 & 404 & 166 & 166 & 166 & 166 \\
\hline Number of responses (events) & 36 & 36 & 17 & 17 & 17 & 17 \\
\hline Number of observations & 1,944 & 1,944 & 882 & 882 & 882 & 882 \\
\hline
\end{tabular}

NOTE: Numbers in parentheses are $z$-statistics; ${ }^{*}$ and ${ }^{* * *}$ indicate statistical significance at the 10 and 1 percent levels, respectively. See notes for Tables 1, 2, and 5 for definitions. 
Table 10

Determinants of Mergers for Distressed Firms

\begin{tabular}{|c|c|c|c|c|c|c|}
\hline & \multicolumn{6}{|c|}{ Stratified Cox hazard ratios: Mergers } \\
\hline & (1) & (2) & (3) & (4) & (5) & (6) \\
\hline Firm size & $\begin{array}{c}1.169 \\
(1.95)^{*}\end{array}$ & $\begin{array}{l}1.115 \\
(1.40)\end{array}$ & $\begin{array}{r}0.904 \\
(-0.78)\end{array}$ & $\begin{array}{r}0.842 \\
(-0.83)\end{array}$ & $\begin{array}{r}0.971 \\
(-0.35)\end{array}$ & $\begin{array}{r}0.820 \\
(-1.55)\end{array}$ \\
\hline MB ratio & $\begin{array}{r}0.643 \\
(-1.27)\end{array}$ & $\begin{array}{c}0.601 \\
(-1.98)^{* *}\end{array}$ & $\begin{array}{r}0.766 \\
(-0.81)\end{array}$ & $\begin{array}{r}0.871 \\
(-0.39)\end{array}$ & $\begin{array}{c}0.423 \\
(-1.31)\end{array}$ & $\begin{array}{c}0.689 \\
(-1.30)\end{array}$ \\
\hline ROE & $\begin{array}{l}2.026 \\
(7.08)^{* * *}\end{array}$ & $\begin{array}{l}2.087 \\
(9.26)^{* * *}\end{array}$ & $\begin{array}{l}2.096 \\
(4.81)^{* * *}\end{array}$ & $\begin{array}{l}2.319 \\
(4.95)^{* * *}\end{array}$ & $\begin{array}{l}1.950 \\
(5.12)^{* * *}\end{array}$ & $\begin{array}{l}2.094 \\
(5.06)^{* * *}\end{array}$ \\
\hline Interest coverage ratio & $\begin{array}{r}0.561 \\
(-1.61)\end{array}$ & $\begin{array}{r}0.599 \\
(-1.39)\end{array}$ & $\begin{array}{r}0.390 \\
(-1.07)\end{array}$ & $\begin{array}{r}0.307 \\
(-1.31)\end{array}$ & $\begin{array}{r}0.449 \\
(-0.96)\end{array}$ & $\begin{array}{r}0.410 \\
(-0.99)\end{array}$ \\
\hline Political connection & $\begin{array}{l}2.064 \\
(1.13)\end{array}$ & & & & & \\
\hline Group affiliation & & $\begin{array}{c}4.368 \\
(1.71)^{*}\end{array}$ & & & & \\
\hline $\begin{array}{l}\text { Largest blockholder } \\
\text { ownership }\end{array}$ & & & $\begin{array}{l}1.055 \\
(2.96)^{* * *}\end{array}$ & & & \\
\hline $\begin{array}{l}\text { Summed ownership } \\
\text { concentration }\end{array}$ & & & & $\begin{array}{l}1.069 \\
(2.15)^{* *}\end{array}$ & & \\
\hline $\begin{array}{l}\text { Largest management } \\
\text { blockholder }\end{array}$ & & & & & $\begin{array}{r}0.934 \\
(-0.85)\end{array}$ & \\
\hline $\begin{array}{l}\text { Largest nonmanagement } \\
\text { blockholder }\end{array}$ & & & & & & $\begin{array}{l}1.067 \\
(3.62)^{* * *}\end{array}$ \\
\hline Log pseudo-likelihood & -45.20 & -43.41 & -25.81 & -24.60 & -26.84 & -24.78 \\
\hline Number of firms & 406 & 406 & 166 & 166 & 166 & 166 \\
\hline Number of responses (events) & 12 & 12 & 8 & 8 & 8 & 8 \\
\hline Number of observations & 1,944 & 1,944 & 882 & 882 & 882 & 882 \\
\hline
\end{tabular}

NOTE: Numbers in parentheses are z-statistics; ${ }^{*}, * *$ and ${ }^{* * *}$ indicate statistical significance at the 10,5 , and 1 percent levels, respectively. See notes for Tables 1, 2, and 5 for definitions. 


\section{REFERENCES}

Ang, James S.; Chua, Jess H. and McConnell, John J. "The Administrative Costs of Corporate Bankruptcy: A Note.” Journal of Finance, March 1982, 37(1), pp. 219-26.

Asquith, Paul; Gertner, Robert and Scharfstein, David. "Anatomy of Financial Distress: An Examination of Junk-Bond Issuers.” Quarterly Journal of Economics, August 1994, 109(3), pp. 625-58.

Atanassov, Julian and Kim, E. Han. "How Do Labor Laws and Investor Protection Affect Corporate Restructuring?" Working paper, University of Michigan, 2006.

Beck, Thorsten; Demirgüç-Kunt, Asli and Maksimovic, Vojislav. "Financing Patterns Around the World: Are Small Firms Different?” Journal of Financial Economics, September 2008, 89(3), pp. 467-87.

Brown, David T.; James, Christopher M. and Mooradian, Robert. "The Information Content of Distressed Restructurings Involving Public and Private Debt Claims." Journal of Financial Economics, February 1993, 33(1), pp. 93-118.

Brown, David T.; James, Christopher M. and Mooradian, Robert. "Asset Sales by Financially Distressed Firms.” Journal of Corporate Finance, August 1994, 1(2), pp. 233-57.

Claessens, Stijn; Djankov, Simeon and Klapper, Leora. "Resolution of Corporate Distress in East Asia.” Journal of Empirical Finance, February 2003, 10(1-2), pp. 199-216.

Claessens, Stijn; Djankov, Simeon and Lang, Larry H.P. "The Separation of Ownership and Control in East Asian Corporations.” Journal of Financial Economics, October-November 2000, 58(1-2), pp. 81-112.

Claessens, Stign; Djankov, Simon and Mody, Ashoka, eds. Resolution of Financial Distress: An International Perspective on the Design of Bankruptcy Laws. Washington, DC: World Bank, 2001.

Cox, D.R. "Regression Models and Life-Tables.” Journal of the Royal Statistical Society, 1972, 34(2), pp. 187-220.

Erwin, Gayle R. and McConnell, John J. "To Live or Let Die? An Empirical Analysis of Piecemeal Voluntary Corporate Liquidations.” Journal of Corporate Finance, December 1997, 3(4), pp. 325-54.

Faccio, Mara; Masulis, Ronald W. and McConnell, John J. "Political Connections and Corporate Bailouts." Journal of Finance, December 2006, 61(6), pp. 2597-635.

Franks, Julian R. and Torous, Walter N. “An Empirical Investigation of U.S. Firms in Reorganization.” Journal of Finance, July 1989, 44(3), pp. 747-69.

Friedman, Eric; Johnson, Simon and Mitton, Todd. "Propping and Tunneling." Journal of Comparative Economics, December 2003, 31(4), pp. 732-50.

Gilson, Stuart C. "Management Turnover and Financial Distress.” Journal of Financial Economics, December 1989, 25(2), pp. 241-62.

Gilson, Stuart C. "Bankruptcy, Boards, Banks, and Blockholders: Evidence on Changes in Corporate Ownership and Control When Firms Default.” Journal of Financial Economics, October 1990, 27(2), pp. 355-87.

Gilson, Stuart C.; Kose, John and Lang, Larry H.P. “Troubled Debt Restructurings: An Empirical Study of Private Reorganization of Firms in Default.” Journal of Financial Economics, October 1990, 27(2), pp. 315-53. 


\section{Sengupta and Faccio}

Greene, William H. Econometric Analysis. Fifth Edition. Upper Saddle River, NJ: Prentice Hall, 2003.

Hoshi, Takeo; Kashyap, Anil and Scharfstein, David. "Corporate Structure, Liquidity and Investment: Evidence from Japanese Industrial Groups.” Quarterly Journal of Economics, February 1991, 106(1), pp. 33-60.

Hotchkiss, Edith S. "Postbankruptcy Performance of Management Turnover." Journal of Finance, March 1995, $50(1)$, pp. 3-21.

Hsieh, David A.; Manski, Charles F. and McFadden, Daniel. "Estimation of Response Probabilities from Augmented Retrospective Observations." Journal of the American Statistical Association, September 1985, 80(391), pp. 651-62.

Kim, Se-Jik. "Bailout and Conglomeration.” Journal of Financial Economics, February 2004, 71(2), pp. 315-47.

Lang, Larry H.P.; Poulsen, Annette and Stulz, Rene M. “Asset Sales, Firm Performance, and the Agency Costs of Managerial Discretion.” Journal of Financial Economics, January 1995, 37(1), pp. 3-37.

La Porta, Rafael; Lopez-de-Silanes, Florencio and Shleifer, Andrei. "Corporate Ownership Around the World." Journal of Finance, April 1999, 54(2), pp. 471-517.

Mitton, Todd. "A Cross-Firm Analysis of the Impact of Corporate Governance on the East Asian Financial Crisis." Journal of Financial Economics, May 2002, 64(2), pp. 215-41.

Morck, Randall, and Nakamura, Masao. "Banks and Corporate Control in Japan.” Journal of Finance, February 1999, 54(1), pp. 319-39.

Morck, Randall; Wolfenzon, Daniel and Yeung, Bernard. "Corporate Governance, Economic Entrenchment, and Growth.” Journal of Economic Literature, September 2005, 43(3), pp. 655-720.

Peek, Joe and Rosengren, Eric S. "Unnatural Selection: Perverse Incentives and the Misallocation of Credit in Japan.” American Economic Review, September 2005, 95(4), pp. 1144-166.

Radelet, Steven and Sachs, Jeffrey D. “The East Asian Financial Crisis: Diagnosis, Remedies, Prospects.” Brookings Papers on Economic Activity, 1998, Issue 1, pp. 1-90.

Reinhart, Carmen and Rogoff, Kenneth. This Time Is Different: Eight Centuries of Financial Folly. Princeton, NJ: Princeton University Press, 2009.

Senbet, Lemma W. and Seward, James K. “Financial Distress, Bankruptcy and Reorganization,” in R.A. Jarrow, V. Maksimovic, and W.T. Ziemba, eds., Handbook of Operations Research and Managerial Sciences. New York: Elsevier, 1995, pp. 921-61.

Tashjian, Elizabeth; Lease, Ronald C. and McConnell, John J. "Prepacks: An Empirical Analysis of Prepackaged Bankruptcies.” Journal of Financial Economics, January 1996, 40(1), pp. 135-62.

Wheelock, David C. and Wilson, Paul W. "Why Do Banks Disappear? The Determinants of U.S. Bank Failures and Acquisitions.” Review of Economics and Statistics, February 2000, 82(1), pp. 127-38. 


\section{APPENDIX \\ Examples of News Articles from the TCR Asia Pacific Archive from the InterNet Bankruptcy Library Website17}

\section{A.1 Example of a Lengthy Workout Process}

\section{WEMBLEY INDUSTRIES: Proposes Debt Restructuring (TCR Asia Pacific: Thursday, December 16, 1999, Vol. 2, No. 245)}

Wembley Industries Holdings Bhd (WIHB) has proposed a debt restructuring exercise involving an issuance of irredeemable convertible unsecured loan stocks (Iculs), a rights issue with warrants and an increase in authorized share capital.

The company said in a statement yesterday the proposed debt restructuring would involve an issuance of RM606mil nominal value of 1 percent Iculs at 100 percent of its nominal value as full and final settlement of loans owing by WIHB and two of its subsidiaries Plaza Rakyat Sdn Bhd and Wembley IBAE Sdn Bhd (IBAE) amounting to approximately RM606mil.

The proposed rights issue would involve 144.475 million new shares and the same number of detachable warrants on the basis of one new share with one detachable warrant for each existing share held, to be issued at RM1 per new share. The company's authorised share capital is proposed to be increased from RM500mil, comprising 500 million shares, to RM1.5bil.

The proposed debt restructuring involves the restructuring of the secured loans, unsecured loans and amounts owing to certain creditors of WIHB, Plaza Rakyat and IBAE. Included in the proposed debt restructuring are the loans and amounts owing by IBAE, a 99.9 percent owned subsidiary of WIHB that is being wound up.

"As WIHB acted as guarantor for the loans of IBAE, the said loans and amounts owing are being restructured together with WIHB and Plaza Rakyat's loans owing," the company said.

As full and final settlement of the loans and amounts owing, Wembley is proposing to issue RM606mil nominal value of Iculs to the secured and unsecured lenders of WIHB, secured lenders of Plaza Rakyat, unsecured lenders of IBAE and the major creditors of WIHB, Plaza Rakyat and IBAE. The RM606mil includes the capitalised interest in respect of the loans, as follows:

- Interest outstanding up to Dec 31, 1998, amounting to RM56mil; and

- Further interest accruing from Jan 1 to Dec 31, 1999, on the principal amount after adjusting for the capitalisation of the outstanding interest set out above at an annual interest rate of 7.25 percent, amounting to RM25mil. However, no interest will be capitalised in respect of the amounts owing to the creditors.

The WIHB group's total debts due to the lenders amounts to RM369mil including interest accrued as of Dec 31, 1998, and further interest accruing up to Dec 31, 1999, while the amount due to creditors is RM238mil. It said WIHB group's current prospects lied mainly in a mixed development project comprising a retail shopping complex, office tower, hotels and an integrated transport hub housing the central bus terminal and the Light Rail Transit station known as the Plaza Rakyat project. Plaza Rakyat, the company's wholly-owned subsidiary, is the sole developer of the project.

"The successful development of the Plaza Rakyat project will depend on the successful deployment of funds towards the Plaza Rakyat project which, in turn, is dependent on the successful implementation of the proposed debt restructuring," it said. (Star Online 15-Dec-1999)

\section{WEMBLEY INDUSTRIES: Workout Scheme Under Revision (TCR Asia Pacific: Monday, July 9, 2001, Vol. 4, No. 132)}

Wembley Industries Holdings Berhad is currently working on a revised proposed debts restructuring scheme and discussions with the company's creditors which include financial institutions are still ongoing. However, as the revised proposed debt restructuring scheme has not been finalized yet, the company could not yet provide details of the scheme.

\footnotetext{
${ }^{17}$ Used with permission. The TCR Asia Pacific is co-published by Bankruptcy Creditors' Services, Inc., and Beard Group, Inc.
} 


\section{Sengupta and Faccio}

In a separate announcement, pursuant to Section 5 of PN4, on 2 July 2001, the Company submitted an application to the Kuala Lumpur Stock Exchange (KLSE) for an extension of time to obtain all the approvals necessary to implement its plan to regularize its financial condition.

\section{Background}

The Wembley Group's present focus is the implementation of the Plaza Rakyat project. Following the liquidation and disposal of several of its principal subsidiaries in 1999 and 2000, the Group's financial viability hinges on the successful outcome of its proposed debt restructuring and rights issue, which was announced in December 1999.

Helmed by subsidiary Clifford Investments Ltd, construction works for the development of the Plaza Rakyat project are currently progressing at a slower pace. The Group is concentrating on the development of the inter-state bus and taxi terminal, the retail podium and the budget hotel while other components such as the office tower, service apartment and a 4-star hotel have been rescheduled and [are] to be undertaken in the near future.

Interim funding from its corporate proposals would enable the Group to expedite the completion of the terminal, podium and hotel and subsequently to generate development profit. As of November 2000, approvals from the SC and Wembley's shareholders are still pending.

\section{WEMBLEY INDUSTRIES: Proposed Debt Plan Still in Works} (TCR Asia Pacific: Monday, October 8, 2001, Vol. 4, No. 196)

Wembley Industries Holdings Berhad is working on a revised proposed debts restructuring scheme and [is] in discussions with the Group's banks/creditors. The details of the proposed debts restructuring scheme have not been finalized.

\section{Background}

On 2 July 2001, the Company submitted an application to the Exchange pursuant to Section 5 of PN4 for an extension of time to obtain all the necessary approvals to implement the plan to regularize its financial position. Subsequently, on 3 August 2001, the Exchange approved the extension of two (2) months from 23 June 2001 to 22 August 2001 to the Company. In approving the extension, the Company is required, within the extension period, to carry out the following:

(i) revise its regularization plan;

(ii) make a revised requisite announcement to the Exchange;

(iii) submit its revised plan to the regulatory authorities for approval; and

(iv) upon submission of the revised plan to the regulatory authorities, make a separate application to the Exchange to seek an additional time for the Company to obtain all the necessary approvals from the authorities.

On 16 August 2001, the Company's financial adviser, Alliance Merchant Bank Berhad (AMBB), submitted an application to the Exchange for a further three (3) month extension from 22 August 2001 to 22 November 2001, to carry out the above requirements. On 21 September 2001, AMBB announced the Exchange had approved the further extension of time for a period of two (2) months from 23 August 2001 to 22 October 2001 to enable the Company to release the requisite announcement.

\section{WEMBLEY INDUS.: Creditors OK Revised Debt Restructuring Plan (TCR Asia Pacific: Wednesday, May 08, 2002, Vol. 5, No. 90)}

Wembley Industries Holdings Berhad is an affected listed issuer pursuant to Practice Note No. 4/2001 as the Auditors of the Company had expressed a disclaimer opinion of the going concern of the Company and its subsidiaries. As an affected listed issuer, the Company has its obligations under PN4.

On 1 March 2002, Alliance Merchant Bank Berhad, on behalf of the Company announced that the Company was not able to make the Requisite Announcement by the deadline of 28 February 2002 laid down by the Exchange on 25 January 2002. The Exchange approved an application made to the Exchange on 1 March 2002 for a further extension of time to 30 April 2002 to make the Requisite Announcement on 18 April 2002.

An application was made to the Exchange on 26 April 2002 to further extend the date to make the Requisite Announcement from 30 April 2002 to 30 June 2002. This extension is pending the approval of the Exchange.

\section{STATUS OF PROPOSED RESTRUCTURING}

On 14 December 1999, AMBB, on behalf of the Board of Directors of the Company, announced the following:

(i) proposed debt restructuring involving the issue of approximately RM606 million nominal value of 1 percent irredeemable unsecured loan stocks (ICULS) at 100 percent of its nominal value as full and final settlement of the loans and amounts owning by the Company and its two subsidiaries namely, Plaza Rakyat Sdn. Bhd. and 
Wembley I.B.A.E. Sdn. Bhd. amounting to RM606 million (inclusive of interests on loans) (Proposed Debt Restructuring);

(ii) proposed rights issue of 144,475,000 new ordinary shares of RM1.00 each together with 144,475,000 detachable warrants on the basis of one (1) new ordinary share with one (1) detachable warrant for every one (1) ordinary share held at an issue of RM1.00 per new rights share (Proposed Rights Issue); and

(iii) proposed increase in the authorized share capital of the Company from the existing RM500,000,000 comprising $500,000,000$ ordinary shares of RM1.00 each to 1,500,000,000 comprising 1,500,000,000 ordinary shares of RM1.00 each.

Applications were submitted to the Securities Commission (SC) and the Foreign Investment Committee (FIC) on 16 December 1999. The FIC had on 26 February 2000 approved the Proposed Debt Restructuring subject to the approval of the SC and that the Bumiputra equity interest in the Company be increased to 30 percent before 31 December 2000. The Company is expected to seek an extension for the compliance upon receipt of the SC's approval for the proposals. The above proposals are pending the approvals of the SC and the shareholders of the Company. Currently, the Company is working on a revised proposed debt restructuring scheme (Revised Proposed Debt Restructuring) and is in discussion with the Group's banks/creditors. As at the date of this announcement, the details of the proposed debts restructuring scheme have not been finalized yet.

As at to date, five (5) financial institutions, Pengurusan Danaharta Nasional Berhad and two (2) creditors have confirmed that they are agreeable to the Revised Proposed Debt Restructuring subject to, inter-alia, approvals of other creditors. The Company has yet to receive the outstanding approval or consent from a major creditor involved in the Revised Proposed Debt Restructuring.

\section{OTHER MATTERS IN RESPECT OF PRACTICE NOTE N0. 10/2001}

On 7 September 2001, the Company announced to the Exchange that the Company is deemed an affected issuer pursuant to paragraph 2.1(c) of the Practice Note No. 10/2001 (PN10). Under paragraph 2.1(c) of PN10, a listed issuer, who has an insignificant business or operations, is deemed to have [an] inadequate level of operations. Insignificant business or operations means business or operations [that generate] revenue on a consolidated basis that represents 5 percent or less of the issued and paid-up share capital of the listed issuer.

As an affected listed issuer under PN10, the Company must comply with the obligations set out in paragraph 6 of PN10. The Exchange has informed the Company that since the Company is also an affected issuer under PN4, the requirements and obligations of PN4 would prevail over those of PN10. It is expected that the Company's regularization plan would address both its financial condition (PN4) and the level of operations (PN10) to warrant a continuing listing on the Official List.

\section{WEMBLEY INDUSTRIES: Finalizes Proposed Debt Restructuring Docs (TCR Asia Pacific: Wednesday, September 04, 2002, Vol. 5, No. 175)}

Wembley Industries Holdings Berhad had on 31 July 2002 via its financial adviser made the Requisite Announcement pursuant to PN4 to regularize the financial condition of the Company and its subsidiaries.

On 9 August 2002, the Exchange approved the Company's application dated 31 July 2002 to extend the time from 1 August 2002 to 30 September 2002 to enable the Company to submit the Proposed Debt Restructuring, the Proposed Capital Reduction and Consolidation and the Proposed Rights Issue (which were announced on 31 July 2002) to the relevant authorities.

The Company is currently preparing and finalizing its applications for submission to the relevant authorities.

The Company is also an affected listed issuer under Practice Note 10/2001 (PN10) of the LR. As such, the Company must comply with the obligations set out in paragraph 6 of PN10. The Exchange has informed the Company that since the Company is an affected issuer under PN4, the requirements and obligations of PN4 would prevail over those of PN10. The proposals announced in the Requisite Announcement would enable the Company to address both its financial condition (PN4) and the level of operations (PN10) to warrant a continuing listing on the Official List.

\section{WEMBLEY INDUSTRIES: FIC Grants Proposals Approval (TCR Asia Pacific: Wednesday, January 15, 2003, Vol. 6, No. 10)}

Further to the announcements dated 30 October 2002, Wembley Industries Holdings Berhad is pleased to announce that the Foreign Investment Committee has, by its letter dated 7 January 2003, approved the Proposals subject to the condition that the FIC would review the equity structure of WIHB three (3) years after the completion of the Proposals. The said letter of approval from the FIC was received on the 10 January 2003. 


\section{Sengupta and Faccio}

The Proposals entail:

i. Proposed Capital Reduction and Consolidation;

ii. Proposed Debt Restructuring;

iii. Proposed Rights Issue; and

iv. Proposed Increase in Authorized Share Capital

\section{A.2 Examples of Workouts}

\section{ANAM GROUP: Anam Group's Workout Details}

(TCR Asia Pacific: Monday, November 2, 1998, Vol. 1, No. 177)

The Korean Herald published more details on the restructuring program underway at the Anam Group, the 21st largest Korean corporation and the world's largest semiconductor packaging company. Anam, with 25 percent of the global market share in chip packaging, has reportedly been profitable until last year.

Three of the group's affiliates applied for a workout program on October 24th 1998. The three companies are Anam Semiconductor Company, Anam Electronics Company, and Anam Environment Company. Another arm of Anam, Anam Construction Company, applied for court receivership.

Anam is seeking $\$ 2.5$ billion either from new loans or via the sale of assets. It has already agreed to sell $\$ 600$ million in assets (specifically four chip packing plants) to the investors through Solomon Smith Barney and Boston Bank. This $\$ 600$ million is earmarked to reduce cross debt guarantees amoung Anam's subsidiaries and to repay some debts.

KOREA EXPRESS: Court OKs Debt Rescheduling Plan (TCR Asia Pacific: Thursday, June 14, 2001, Vol. 4, No. 116)

The Seoul District Court has approved the debt rescheduling plan of Korea Express Company, The Asian Wall Street Journal reported Tuesday.

The court-approved plan will call for the conversion of the bankrupt logistics company's debts totaling W271.3 billion into equity, while other debts amounting to W416.3 billion will be written off by creditor banks.

Moreover, the company will make repayments on debts worth W778.5 billion to creditor banks, the newspaper reports.

\section{GREAT RIVER: Reaches Debt Workout Agreement With Creditors} (TCR Asia Pacific: Monday, January 14, 2002, Vol. 5, No. 9)

Garment maker PT Great River International Tbk has reached an agreement with its creditors for restructuring of debts worth US\$172.5 million, IndoExchange reports, citing President Director Sunjoto Tanudjaja's letter to the Jakarta Stock Exchange (JSX).

The restructuring will be carried out through a debt-to-equity swap scheme. Part of the debt will be rescheduled for 8 years without any grace period, Tanudjaja added though declined to elaborate the composition of share ownerships after the restructuring.

$T C R A P$ reported May last year that it planned to use its assets as collateral in its proposed debt-restructuring program, which has been signed with the company's creditors.

\section{A.3 Examples of Asset Sales}

APO CEMENT: JG Summit Finalizes Sale of Apo (TCR Asia Pacific: Monday, February 22, 1999, Vol. 2, No. 36)

Publicly listed JG Summit Holdings, Inc. sold on Wednesday its entire shareholdings in cement subsidiary, Apo Cement Corp., to both local and foreign affiliates of Mexico-based Cemex S.A. de CV for \$401.5 million.

In a disclosure to the local stock exchange, JG corporate secretary Emmanuel C. Rojas, Jr. said the buyers include Triple Dime Holdings, Inc., a Philippine-based affiliate of Cemex.

The Gokongwei-owned cement firm, which used to hold 99.9 percent stake in Apo, divested its equity and debt interests to Triple Dime for $\$ 191.5$ million. 
Analysts told BusinessWorld yesterday that the company might have been formed by Cemex as an acquisition vehicle since Philippine laws only allow 40 percent foreign ownership in public utilities.

Meanwhile, the rest of Apo's loans including its foreign currency denominated-debts worth \$210 million were absorbed by a number of foreign affiliates which the company did not identify. (BusinessWorld 19-Feb-1999)

HYUNDAI ENGIN.\& CONST.: Downsizing, Selling Off

(TCR Asia Pacific: Thursday, August 17, 2000, Vol. 3, No. 160)

Hyundai Engineering \& Construction (HDEC) is striving to downsize and sell off securities and real estate.

An HDEC official said yesterday that the company is pushing to downsize the organization and realign personnel to improve efficiency. He said a substantial part of staff in the management department will be moved into [the] sales department.

The company has 7,000 employees with 250 directors and executives. The downsizing was part of the company's selfrescue plan submitted to main creditor Korea Exchange Bank Sunday. HDEC also formed a 15-member executive committee to carry out its self-rescue plan Monday.

The committee will coordinate repayment of 1.52 trillion won ( $\$ 1.36$ billion) out of the company's total 6 trillion won debt by the end of this year and sell a 6.1-percent stake in Hyundai Motor controlled by Hyundai founder Chung Ju-yung. HDEC also said it will sell its office building near Kwanghwamun to Hyundai Marine and Fire Insurance for 90 billion won with 18 billion won of that going to pay down debt.

\section{WICAKSANA OVERSEAS: Shareholders OK Jakarana Stake Sale} (TCR Asia Pacific: Tuesday, July 3, 2001, Vol. 4, No. 129)

PT Wicaksana Overseas International Tbk, in its Annual General Meeting on Thursday, approved the 60 percent stake sale of subsidiary PT Jakarana Tama to Batavia Investment Ltd for US\$6.43 million to comply with the company's debt restructuring deal with its creditors, AFX reports Thursday.

Deputy Finance Director Elys Karis said the company has not been able to make up for the losses brought about by the termination of its contract with Batavia Investment.

According to AFX, the company has previously said the termination of the BAT contract will hit earnings in the first half, with recovery expected in the third and fourth quarters as the company secures new contracts with other producers. It has projected a net loss of Rp128.6 billion this year and sales of Rp2.341 trillion, against a net loss of Rp201 billion and sales of Rp2.541 trillion last year.

FIRST PHILIPPINE: Unit Sells $\mathbf{5 0} \%$ Stake in PPC to Claredon (TCR Asia Pacific: Thursday, July 03, 2003, Vol. 6, No. 130)

In a disclosure to the Philippine Stock Exchange, First Philippine Holdings Corporation power generation unit First Generation Holdings Corporation sold on June 27 its 50 percent ownership interest in Panay Power Corporation to Claredon Towers Holdings, Inc. a wholly-owned subsidiary of First Metro Investment Corporation for P1,164,500,000. PPC owns and operates a $72 \mathrm{MW}$ bunker diesel power plant in Barangay Ingore, Lapaz, Iloilo. Likewise, First Private Power Corporation which is 40 percent owned by First Gen, sold its 20 percent ownership stake in PPC to Claredon Towers for P465,800,000.

Panay Electric Company (PECO), the power distribution Company operating in Iloilo, also informed FPHC that it sold its 30 percent in PPC for P698,700,000 thus completing the acquisition by Claredon Towers of the interest of the shareholders of PPC for the total amount of P2,329,000,000. FPHC holds a 30 percent stake in PECO.

\section{A.4 Examples of Mergers and Liquidations}

LG IND. SYSTEMS: Two LG Subsidiaries Headed for Merger

(TCR Asia Pacific: Monday, December 14, 1998, Vol. 1, No. 206)

Digital Chosunllbo reports LG Ind. Systems announced Friday that it has decided to merge with LG Metals to operate as a single new company from May 1 next year. The merger will increase the paid-in capital of the LG subsidiary up to W148.1 billion and yearly sales are expected to reach W3.7 trillion. The company will see its electric power systems and elevator divisions reinforced by the merger, a company official said. 


\section{Sengupta and Faccio}

\section{KIA MOTORS: Kia Restructures Before Hyundai Assumes Control (TCR Asia Pacific: Monday, January 4, 1999, Vol. 1, No. 1)}

The Korea Herald reported details of the steps that Kia Motors Company and its sister bus and truck maker the Asia Motors Company will take before they are completely taken over by Hyundai Motors Company. The steps will involve the reduction of Kia's 37.8 billion won worth of capital by 90 percent prior to a later capital injection that will raise the company's capital to 1.5 trillion won. These moves will prepare Kia for Hyundai to amass a 51 percent stake in the auto maker.

According to sources in the Korea Stock exchange, old Kia shares will be converted into new shares at a ratio of 10 to 1 (i.e., ten old shares will be equivalent to one new share). Following this, a consortium of five Hyundai affiliated companies will buy 153 million shares of Kia at a price of 5,500 won per share. This will result in Hyundai having a 51 percent stake in the company. Creditor banks will also convert their debt into a total of 120 million shares (at a rate of 15,000 won per share) giving them 40 percent of the company.

Hyundai Motors Company, Korea's largest automobile manufacturer, was the winner of an international auction of the bankrupt Kia Motors Company and the Asia Motors Company.

Kia Motors became insolvent last July. Kia Motors and Asia Motors were granted protection from creditors under court receivership in October 1997.

\section{MONALISA CO: Completes Liquidation Plan}

(TCR Asia Pacific: Tuesday, February 16, 1999, Vol. 2, No. 32)

According to the Korean language Maeil Kyungje's Business Brief section, the Monalisa Company's liquidation plan was approved by the Seoul District Court.

This firm is a major toilet paper and tissue producer in Korea, and filed for court receivership on June 13, 1998. It was granted receivership on October 8th, 1998.

\section{HANYANG CORP.: Court to Liquidate} WOOSUNG CONSTRUCTION: Court to Liquidate (TCR Asia Pacific: Thursday, December 7, 2000, Vol. 3, No. 238)

The Seoul District Court has decided to liquidate Hanyang Corp. and Woosung Construction, both of which have been operating under court supervision.

The two construction firms had been healthy until the end of last year, with Hanyang ranking 18th nationally in terms of sales and Woosung 37th in 1999. The court said it decided to liquidate the two as both showed little hope of survival. In the case of Hanyang, its two largest shareholders, state-run firms the Korea National Housing Corp. (KNHC) and the Korea Asset Management Co. (KAMCO) decided that they would no longer provide operational support and in the case of Woosung, its debts have continued to snowball since late last year. (Digital Chosun 05-Dec-2000)

\section{AUTOWAYS HOLDINGS: KLESE Removing Securities Trading by Aug 11 (TCR Asia Pacific: Wednesday, July 30, 2003, Vol. 6, No. 149)}

Autoways Holdings Berhad (In Liquidation) informed that the Kuala Lumpur Stock Exchange (KLSE) had written to the Official Receiver and the Company and advised that they, after having considered all the facts and circumstances of the matter and upon consultation with the Securities Commission, in the exercise of its powers under paragraph 16.17 of the KLSE's Listing Requirements has decided to de-list the securities of AUTOWAY from the Official List of the KLSE as AUTOWAY does not have an adequate level of financial condition to warrant continued listing on the Official List of the KLSE.

Accordingly, the securities of AUTOWAY will be removed from the Official List of the KLSE at 9:00 a.m. on Monday, 11 August, 2003.

The securities of AUTOWAY, which are deposited with the Malaysian Central Depository Sdn. Bhd. (MCD), may remain deposited with the MCD notwithstanding the de-listing of the securities of AUTOWAY from the Official List of the KLSE. It is not mandatory for the securities of AUTOWAY to be withdrawn from MCD. 